\title{
DISCLAIMER
}

This report was prepared as an ascount of work sponsored by an agency of the United States Government. Neither the United Sitates Government nor any agency thereof, nor any of their employees, makes any warranty, express or implied, or assumes any legal liability or responsibility for the accuracy, completeness, or usefulness of any information, apparatus, product, or process disclosed, or represents that its use would not infringe privately owned rights. Reference herein to any specific commerciill product, process, or service by trade name, trademark, manufacturer, or oti.erwise does not. necessarily constitute or imply its endorsement, recommendation, of favoring $b_{j}$ the Uinted States Government or any agency thereof. The views and opinions of authors expressed herein do not necessarily state or reflect those of the United States Government or any agency thereof.

\section{Index of}

Available Resources

November 1992

Document Number: DOE/CH/10402--20 


\section{The Council of State Governments}

For more than half a century, the Council of State Governments has served as a common ground for the states of the nation. The Council is a non-profit, state-supported and -directed service organization that provides research and resources, identifies trends, supplies answers and creates a network for legislative, executive and judicial branch representatives.

Through its national headquarters in Lexington, Kentucky, a state-federal office in Washington, D.C., and regional offices in New York, Atlarta, Chicago (Lombard) and San Francisco, CSG is dedicated to preserving the role of states in America's federal system.

The role of the Midwestern Office of the Council of State Governments is to foster intergovernmental cooperation through the promotion of regional, as well as individual, state responses to common issues and challenges.

\section{Index of Available Resources}

This report was prepared with the support of the U.S. Department of Energy, Cooperative Agreement No. DE-FC02-89 CH10402. However, any opinions, findings, conclusions, or recommendations expressed herein are those of the author(s) and do not necessarily reflect the views of DOE.

The purpose of the agreement, and reports issued pursuant to it, is to identify and analyze regional issues pertaining to the transportation of high-level radioactive waste and tn inform Midwestern state officials with respect to technical issues and regulatory concerns reiated to waste transportation.

In addition to publishing reports related to the transportation of high-level radioactive waste, the Midwestern Office of CSG has compiled a references library on radioactive waste transportation. All materials are available by loan. For more information, contact the Midwestern Office at $708 / 810-0210$.

Prepared by:

Lisa R. Sattler, Policy Analyst Midwestern Office

Council of State Governments

641 E. Butterfield Road, Suite 401 Lombard, IL 60148-5651

(708) $810-0210$ 


\section{American Indians}

Fowler, Catherine S. (09/01/90). Native Americans and Yucca Mountain: A Summary Report. Reference \#006.

Fowler, Catherine S. (10/15/91). Native Americans and Yucca Mountain: A Revised and Updated Summary Report on Research Undertaken Between 1987 and 1991 (Volume I). Reference \#008.

Fowler, Catherine S. (10/15/91). Native Americans and Yucca Mountain: A Revised and Updated Summary Report on Research Undertaken Between 1987 and 1991 (Volume II). Reference $\$ 009$.

Rusco, Elmer R. (10/01/91). Native Americans and State and Local Governments. Reference \#007.

U.S. Department of Energy (01/01/92). U.S. Department of Energy American Indian Policy.

Reference $\$ 005$.

\section{Casks}

Audin, Lindsay (10/01/91). Nuclear Cask Testing Films Misleading and Misused. Reference \#052.

Madsen, Marcella M., and Alan Zimmer (01/01/86). A Truck Cask Design for Shipping Defense High-Level Waste. Reference \#053.

\section{Emergency Response}

U.S. Department of Transportation (RSPA) (01/01/87). Emergency Response Guidebook. Reference $\# 053$.

U.S. Nuclear Regulatory Commission (06/01/92). Emergency Response to a Highway Accident in Springfield, Massachusetts, on December 16, 1991. Reference \#052.

\section{Energy}

Lee, William S. (09/01/90). Energy for Our Globe's People. Reference \#069.

\section{Environmen:}

Blix, Hans (05/29/91). Nuclear Power and the Environment (Presenta:ion at the Seminar "Atomic Energy in Our Changing World," Budapest, May 29, 1991). Reference \#005.

General Accounting Office (04/01/92). Better Management for DOE's Technology Development Program. Reference \#004.

General Accounting Office (09/01/92). Unresolved Issues May Hamper Success of EPA's Proposed Emissions Program. Reference \#009.

O'Connor, Philip R. (05/14/91). Implications of the Clean Air Act on Nuclear Power (Presentation to the Nuclear Power Assembly). Reference \#006. 
U.S. Department of Energy, Nevada Field Office. Desert Tortoise Conservation: Procedures for Conserving Desert Tortoises on the Nevada Test Site. Reference \#007.

\section{Hazardous Waste}

General Accounting Office (06/01/92). Advantages of and Barriers to Reducing the Use of Toxic Chemicals. Reference \#016.

Ceneral Accounting Office (04/01/92). Impediments Delay Timely Closing and Cleanup of Facilities. Reference \#015.

U.S. Department of Transportation (08/31/92). Transportation of Hazardous Materials; Highway Routing; Proposed Rules. Reference \#017.

\section{Interim Storage}

Electric Power Research Institute (04/01/87). NUHOMS Spent-Fuel Storage Demonstration: Program Overview. Reference \#008.

General Acrounting Office (02/01/88). Information on the Reracking of the Diablo Canyon Spent Fuel Storage Poois. Reference \#011.

Gornuley, O.P. (01/01/82). The Role of Dry Storage as a Means to Meet National Storage Needs in the United States. Reference \#010.

Johnson, E.R., and J.A. McBride (01/01/82). Technical and Economic Assessment of Alternative Dry Storage Methods. Reference 1009.

U.S. Department of Energy (02/01/89). Final Version Dry Cask Storage Study. Reference \#007.

U.S. Nuclear Regulatory Commission (08/22/84). The Commission's Decision in the Matter of Rulemaking on the Storage and Disposal of Nuclear Waste (Waste Confidence Rulemaking).

Reference \#006.

\section{Low-Level Waste}

General Accounting Office (10/14/92). Nebraska Low-Level Waste: Supplemental Information. Reference \#012.

General Accounting Office (08/01/92). New York's Adherence to Site Selection Procedures is Unclear. Reference $\# 008$.

Midwest Interstate Low-Level Radioactive Waste Compact Commission (08/01/92). Annual Report for the Period from July 1, 1991, to June 30, 1992. Reference \#010.

Northeast Interstate Low-Level Radioactive Waste Commission (03/01 /92). 1991 Annual Report. Reference \#007.

U.S. Supreme Court (06/23/92). New York v. United States et al. Reference \#011. 
Vanags, U. (for the Maine Low-Level Radioactive Waste Authority) (05/01/92). A Study of Radioactive Wastes. Reference \#009.

\section{Miscellaneous}

American Nuclear Society (01/01/92). World Directory of Radwaste Managers. Reference \#055.

Burns, William, Paul Slovic, Roger Kasperson, Jeanne Kasperson, Ortwin Renn, and Srinivas Emani (09/01/90). Social Amplification of Risk: An Empirical Study. Reference \#052.

Conference of Radiation Control Program Directors, Inc. (10/01/92). Directory of State Agencies Involved with the Transportation of Radioactive Material. Reference $\# 060$.

General Accounting Office (07/01/92). Entertainment Costs Under DOE's Uranium Enrichment Production Contract. Reference \#058.

Loren, Gideon, and Naomi Klein (10/02/91). Bias Against Negative Studies in Newspaper Reports of Medical Research. Reference \#056.

Southern States Energy Board (06/16/92). Transuranic (TRU) Waste Transportation Working Group Meeting Minutes and Proceedings (San Antonio, June 16, 1992). Reference \#057.

U.S. Congress (10/17/86). Emergency Planning and Community Right-to-Know Act of 1986.

Reference \#054.

U.S. Department of Energy (04/20/92). Education Programs Catalog 1992. Reference \#051.

U.S. Department of Energy (06/12/92). Transportation Emergency Preparedness External Coordination (TEC) Working Group Meeting Summary (New Orleans, March 30-April 1, 1992). Reference \#059.

Western Interstate Energy Board (04/16/92). High-Level Radioactive Waste Committee Meeting (Las Vegas, April 16-17, 1992). Reference $\# 053$.

\section{MRS}

Trebules, Victor (10/01/92). Monitored Retrievable Storage Technologies, Operations, and Status of Siting Activities (Presentation before WIEB HLW Committee, Denver, September 30-October 1, 1992). Reference \#015.

Wood, T.W., S.M. Short, M.G. Woodruff, M.K. Altenhofen, and C.A. MacKay (PNL) (04/01/89). MRS Systems Study Task G Report: The Role and Functions of Surface Storage of Radioactive Material in the Federal Waste Management System. Reference \#014.

\section{Nuclear Energy}

Energy Information Administration (10/01 /91). World Nuclear Fuel Cycle Requirements 1991. Reference \#055.

Hohenemser, Christoph, Robert L. Goble, and Paul Slovic (01/01/90). Institutional Aspects of the Future Development of Nuclear Power. Reference \#057. 
Shrader-Frechette, K.S. (01/01/80). Nuclear T echnology. Reference \#059.

Slovic, Paul (01/01/91). Perception of Risk and the Future of Nuclear Power. Reference \#056.

Slovic, Paul (01/01/90). Perception of Risk from Radiation. Reference \#058.

Smith, Sherwood H., Jr. (12/01/91). A Case for Reviving the Nuclear Option. Reference \#054.

\section{NWPA}

General Accounting Office (06/01/92). Status of Actions to Improve DOE User-Fee Assessments. Reference \#023.

General Accounting Office (05/01/92). Questionable Uses of Program Funds at Lawrence Livermore Laboratory. Reference \#024.

General Accounting Office (04/01/90). Quarterly Report as of December 31, 1989. Reference \#027.

General Accounting Office (12/01/89). Quarterly Report on DOE's Nuclear Waste Program as of June 30,1989 . Reference \#026.

General Accounting Office (11/22/88). Comments on the Department of Energy's Implementation of the Nuclear Waste Policy Act. Reference \#039.

General Accounting Office (09/01/88). Fourth Annual Report on DOE's Nuclear Waste Program. Reference \#028.

General Accounting Office (08/01/88). Quarterly Report on DOE's Nuclear Waste Program as of June 30, 1988. Reference \#031.

General Accounting Office (05/01/88). Quarterly Report on DOE's Nuclear Waste Program as of March 31, 1988. Reference \#030.

General Accounting Office (02/01/88). Quarterly Report on DOE's Nuclear Waste Program as of December 31, 1987. Reference \#029.

General Accounting Office (08/01/88). Problems Associated with DOE's Inactive Waste Sites.

Reference $\# 032$.

Nuclear Waste Technical Review Board (06/01/92). Fifth Report to the U.S. Congress and the U.S. Secretary of Energy. Reference \#037.

Nuclear Waste Technical Review Board (12/01/91). Fourth Report to the U.S. Congress and the U.S. Secretary of Energy. Reference \#035.

Nuclear Waste Technical Review Board (05/01/91). Third Report to the U.S. Corıgress and the U.S. Secretary of Energy. Reference \#035.

Nuclear Waste Technical Review Board (03/01/90). First Report to the U.S. Congress and the U.S. Secretary of Energy. Reference \#033.

Reed, J.R., and K.A. Mahoney (NCSL) (05/01/92). Federal Training Assistance for the Transportation of Spent Fuel. Reference \#025. 
Rusche, Ben C. (01/01/86). Status of the United States' High-Level Nuclear Waste Disposal Program. Reference \#038.

Sharp, J., S. Grady, and G. Harrison (12/01/91). Research Paper to Support the Development of Section 180(c) Policy Options (Draft). Reference \#022.

Viebrock, J.M. and N. Mote (Nuclear Assurance Corporation) (05/01/92). Facility Interface Capability Assessment (FICA) Summary Report. Reference \#020.

Viebrock, J.M., and N. Mote (C2/01/92). Near-Site Transportation Infrastructure Project Final Report (Draft). Reference \#021.

\section{OCRWM}

General Accounting Office (09/01/92). Better Information Resources Management Needed to Accomplish Missions. Reference \#034.

OCRWM CSDP Independent Management Review Group (IMRG) (08/24/82). First Report.

Reference \#035.

\section{Kadioactive Waste}

American Society of Civil Engineers and the American Nuclear Society $(04 / 12 / 92)$. High-Level Radioactive Waste Management: Proceedings of the Third International Conference (Volume 1). Reference \#047.

American Society of Civil Engineers and the American Nuclear Society (04/12/92). High-Level Radioactive Waste Management: Proceedings of the Third International Conference (Volume 2). Reference \#048.

General Accounting Office (07/01/92). Improvements Needed in Monitoring Contaminants in Hanford Soils. Reference \#045.

General Accounting Office (06/01/92). Defense Waste Processing Facility - Cost, Schedule, and Technical Issues. Reference \#046.

General Accounting Office (09/01/88). Supplementary Information on Problems at DOE's Inactive Waste Sites. Reference \#049.

National Conference of State Legislatures (12/01/91). NCSL Official Policy on Radioactive Waste Management. ‥ference \#044.

Shrader-Frechette, K.S. $(01 / 01 / 80)$. Nuclear Wastes and the Argument from Ignorance. Reference $\# 051$.

U.S. Department of Energy (12/01/91). Spent Fuel Storage Requirements 1991-2040. Reference \#050.

\section{Rail/Highway}

Carlson, R.W., and L.E. Fischer (LLNL) (06/01/92). A Highway Accident Involving Unirradiated Nuclear Fuel in Springfield, Massachusetts, on December 16, 1991. Reference \#027. 
Conlon, Peter (Association of American Railroads) (05/20/92). Railroad Industry Perspective on the Transportation of Nuclear Waste (Presentation before the Transportation Coordination Group, Phoenix, May 20-21, 1992). Reference \#024.

U.S. Department of Transportation, Research and Special Programs Administration (08/01/92). Guidelines for Selecting Preferred Highway Routes for Highway Route Controlled Quantity Shipments of Radioactive Materials (Update). Reference \#028.

Wentz, Christopher J. (05/20/92). Lessons Learned: State of New Mexico's Experience in the WIPP Highway Route Designation Process. Reference \#025.

Western Interstate Energy Board (09/01/92). Utility Rail Shipments in the Western Region. Reference \#029.

\section{Repository}

Cook, B.J., J.L. Emel, and R.E. Kasperson (01/01/90). Organizing and Managing Radioactive Waste Disposal as an Experiment. Reference \#042.

Flynn, James (04/15/92). How Not to Sell a Nuclear Waste Dump. Reference \#045.

Flynn, James H., C.K. Mertz, and Paul Slovic (05/01/91). Yucca Mountain Socioeconomic Project: The 1991 Nevada State Telephone Survey: Key Findings. Reference \#034.

Flynn, James H., Paul Slovic, C.K. Mertz, ana James Toma (09/01/90). Evaluations of Yucca Mountain Survey Findings About the Attitudes, Opinions, and Evaluations of Nuclear Waste Disposal and Yucca Mountain, Nevada. Reference \#036.

Flynn, James, Roger Kasperson, Howard Kunreuther, and Paul Slovic (01/01/92). Time to Rethink Nuclear Waste Storage. Reference \#046.

Freudenburg, William (09/01/91). Organizational Management of Long-Term Risks: Implications for Risk and Safety in the Transportation of Nuclear Wastes. Reference \#037.

General Accounting Office (05/01/92). DOE's Repository Site Investigations, a Long and Difficult Task. Reference \#032.

Kunreuther, H., D. Easterling, W. Desvousges, and P. Slovic (07/01/90). Public Attitudes Toward Siting a High-Level Nuclear Waste Repository in Nevada. Reference \#041.

Kunreuther, H., W.H. Desvousges, and P. Slovic (10/01/88). Nevada's Predicament. Reference \#043.

Kunreuther, Howard, Doug Easterling, and Paul Kleindorfer (09/01/88). The Convention Planning Process: Potential Impact of a High-Level Nuclear Waste Repository in Nevada. Reference \#03y.

Kunreuther, Howard, Paul Slovic, Joanne Nigg, and William H. Desvousges (09/01/87). Yucca Mountain Socioeconomic Project Report on the 1987 Risk Perception Telephone Surveys. Reference $\# 033$.

Mountain West Research (12/01/89). Yucca Mountain Socioeconomic Project Preliminary Findings: 1989 Nevada State Telephone Survey. Reference \#035. 
Richards, M.D. (USCEA) (04/01/92). Siting Industrial Facilities: Lessons from the Social Science Literature. Reference \#044.

Slovic, P., M. Layman, and J.H. Flynn (04/01/91). Lessons from Yucca Mountain. Reference \#040.

Slovic, Paul, Mark Layman, Nancy N. Kraus, James Chalmers, Gail Gesell, and James Flynn

$(07 / 01 / 89)$. Perceived Risk, Stigma, and Potential Economic Impacts of a High-Level Nuclear Waste Repository in Nevada. Reference \#038.

\section{Transportation}

Binney, Stephen E., and Robert G. Mason (01/01/91). Summary Response of Key Individuals about the Transport of Radioactive Waste from Hanford through Oregon: A Pre-survey. Reference \#087.

Commercial Vehicle Safety Alliance (09/01/91). Recommended National Procedures for the Safety Inspection of Commercial Highway Vehicles Transporting TRU, Spent Fuel, and HLW (Draft). Reference \#100.

General Accounting Office (08/01/87). Shipping Damaged Fuel From Three Mile Island to Idaho. Reference \#095.

MacGregor, Donald, Paul Slovic, Robert G. Mason, and John Detwiller (01/21/91). Transport of Radioactive Waste Through Oregon: Results of a Statewide Survey. Reference \#085.

National Governors' Association and the National Conference of State Legislatures (06/18/92). Alliance Phase One Subgroup Reports (Alliance for Uniform Hazmat Transportation Procedures). Reference \#097.

Oregon Hanford Advisory Committee (12/01/88). Findings, Conclusions, and Recommendations on the Transport of Plutonium-Contaminated Nuclear Weapons Wastes through Oregon. Reference $\# 090$.

Roland, Robert A. (Chemical Manufacturers Association) (02/02/92). Statement on Interstate Transportation and Disposal of Hazardous Waste (Presentation before the National Governors' Association). Reference \#088.

Sattler, Lisa (Midwestern Office of the Council of State Governments) (10/01/92). Handbook of High-Level Radioactive Waste Transportation. Reference \#096.

Shafer, Rebecca L. (NCSL) (07/01/92). Risk Assessment and Communication: Techniques for Managing the Transport of Nuclear Spent Fuel and High-Level Radioactive Waste. Reference \#091.

Sharp, Jerry, Steve Grady, and Glen Harrison (12/01/91). Research Paper to Support the Development of Section 180(c) Policy Options (Draft). Reference \#089.

Simmons, Dale (01/01/91). Personal Values and Public Perspectives on Highway Transport of Radioactive Wastes: A Summary of Significant Findings. Reference \#086.

South Dakota Department of Transportation (09/30/92). Transportation Improvement Program: 1993-1997. Reference \#099.

Tuler, Seth, Roger E. Kasperson, and Samuel Ratick (Clark University) (06/01/88). The Effects of Human Reliability in the Transportation of Spent Nuclear Fuel. Reference \#084. 
U.S. Department of Energy (07/01/92). Transportation Assessment and Integration (TRAIN). Reference \#092.

U.S. Nuclear Regulatory Commission (06/01/92). Public Information Circular for Shipments of Irradiated Reactor Fuel. Reference \#093.

U.S. Nuclear Regulatory Commission (03/01/87). Transporting Spent Fuel: Protection Provided Against Severe Highway and Railroad Accidents. Reference \#094.

Wilmot, Edwin L., and Robert E. Philpott (01/01/86). Transportation Systems to Support the Nuclear Waste Policy Act of 1982. Reference \#098.

\section{WIPP}

U.S. Department of Energy (01/01/92). TRANSAX-90 - A Transportation Exercise Involving a TRUPACT-II Container (Videotape). Reference \#015. 


\section{American Indians}

Foster, Barbara, and James B. Reed (02/01/89). State-Tribal Transportation Agreements. Reference $\# 003$.

Fowler, Catherine S. (10/15/91). Native Americans and Yucca Mountain: A Revised and Updated Summary Report on Research Undertaken Between 1987 and 1991 (Volume I). Reference \#008.

Fowler, Catherine S. (10/15/91). Native Americans and Yucca Mountain: A Revised and Updated Summary Report on Research Undertaken Between 1987 and 1991 (Volume II). Reference \#009.

Fowler, Catherine S. (09/01/90). Native Americans and Yucca Mountain: A Summary Report. Reference \#006.

National Congress of American Indians (06/22/89). Tribal Leaders List. Reference \#002.

Reed James B., and Mara A. Cohen (05/01/91). Jurisdiction Over Nuclear Waste Transportation on Indian Tribal Lands: State-Tribal Relationships. Reference \#001.

Reed, James B. $(09 / 12 / 89)$. Interactions Between States and Tribes (Presentation at the Tribal Seminar on Nuclear Waste). Reference \#004.

Rusco, Elmer R. (10/01/91). Native Americans and State and Local Governments. Reference \#007.

U.S. Department of Energy (01/01/92). U.S. Department of Energy American Indian Policy.

Reference $\# 005$.

\section{Casks}

Audin, Lindsay (10/01/91). Nuclear Cask Testing Films Misleading and Misused. Reference \#052.

Audin, Lindsay (12/01/90). Nuclear Waste Shipping Container Response to Severe Accident Conditions: A Brief Critique of the Modal Study. Reference \#014.

B \& W Fuel Company (02/01/90). Babcock \& Wilcox BR-100 100-Ton Rail/Barge Spent Fuel Shipping Cask (Volume I). Reference \#031.

B \& W Fuel Company (02/01/90̈). Babcock \& Wilcox BR-100 100-Ton Rail/Barge Spent Fuel Shipping Cask (Volume II). Reference \#032.

Babcock and Wilcox (05/01/90). Preliminary Design Report Executive Summary: B - ucock and Wilcox BR-100 Cask. Reference \#005.

Danese, Larry (12/04/90). Facility Constraints (Presentation before the OCRW'A Transportation Coordination Group, Albuquerque). Reference \#042.

Easton, Earl P. (U.S. Nuclear Regulatory Commission) (02/21/90). NRC Ce tification of Shipping Casks (Presentation before the OCRWM Transportation Coordination Gro' $\mathrm{p}$, Lexington). Reference $\# 038$.

Fisher, Margaret W. (U.S. Department of Energy) (02/21/90). Overvic $w$ and Status of the OCRWM Transportation Cask System (Presentation to the OCRWM Transportal on Coordination Group Meeting). Reference \#039. 
General Accounting Office (03/01/92). Development of Casks for Transporting Spent Fuel Needs Modification. Reference \#051.

General Accounting Office (01/01/92). Weak DOE Contract Management Invited TRUPACT-Il Setbacks. Reference \#050.

General Atomics (04/01/90). GA-4/GA-9 Legal Weight Truck From Reactor Spent Fuel Shipping Casks: Preliminary Design Report (Volume I). Reference \#027.

General Atomics (04/01/90). GA-4/GA-9 Legal Weight Truck From Reactor Spent Fuel Shipping Casks: Preliminary Design Report (Volume II). Reference \#028.

General Atomics (05/01/90). Preliminary Design Report Executive Summary: General Atomics GA4/GA-9 Cask. Reference \#004.

Halstead, Robert J., Lindsay Audin, Ray'mond E. Hoskins, and David F. Snedeker (12/01/90). State of Nevada Comments on the OCRWM From-Reactor Spent Fuel Shipping Cask Preliminary Design Reports. Reference \#013.

Halstead, Robert, and Russell di Bartolo. State of Nevada Nuclear Waste Shipping Cask Design Studies. Reference \#040.

Henry, K.H. (EG\&G Idaho) (03/06/90). Cask Systems Development Program (Presentation to the Western Interstate Energy Board's High-Level Waste Committee, Denver). Reference \#008.

Hoess, Joseph A., and Vincent J. Drago (Battol: Me norial Institute) (05/01/89). Study of Minimum-

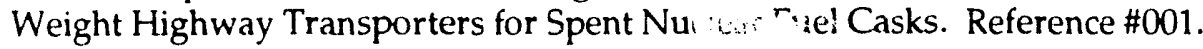

Hoskins, Raymond E. (12/01/90). Nuclear Waste Management Systems Issues Related to Transportation Cask Design: At-Reactor Spyent Fuel Storage, Monitored Retrievable Storage and Modal Mix. Reference \#016.

Johnson, P.E., M.W. Wankerl, and D.S. Joy. Transportation Capabilities of the Existing Cask Fleet. Reference \#048.

Lake, William H. (11/15/90). OCRWM Cask Design Process and Requirements (Presentation to the Midwestern High-level Radioactive Waste Transportation Committee, Minneapolis, November 15-16, 1990). Reference $\# 041$.

Lake, William H. (11/14/90). Cask Systems Development Program (Presentation to the Midwestern High-level Radioactive Waste Transportation Committee, Minneapolis). Reference \#044.

Madsen, Marcella M., and Alan Zimmer (01/01/86). A Truck Cask Design for Shipping Defense High-Level Waste. Reference \#053.

Meyer, Richard (General A tomics) (02/22/90). GA-4 and GA-9 Legal Weight Truck Spent Fuel Shipping Casks (Presentation to the Transportation Coordination Group). Reference \#026.

Nuclear Assurance Corporation (C5/01/90). Preliminary Design Report Executive Summary: Nuclear Assurance Corporation NAC-CTC Cask. Reference \#003.

Nuclear Assurance Corporation (04/01/90). Preliminary Design Report for the NAC Combined Transport Cask (Volume 1). Reference \#033. 
Nuclear Assurance Corporation (04/01/90). Preliminary Design Report for the NAC Combined Transport Cask (Volume II). Reference \#034.

Nuclear Packaging (04/01/90). Development of NuPac 140B 100 Ton Rail/'Barge Cask: Preliminary Design Report (Volume I). Reference \#029.

Nuclear Packaging (04/01/90). Development of NuPac 140B 100 Ton Rail/Barge Cask: Preliminary Design Report (Volume II). Reference \#030.

Nuclear Packaging, Inc. (05/01/90). Preliminary Design Report Executive Summary: Nuclear Packaging NuPac 140B Cask. Reference \#006.

Nuclear Waste Technical Review Board (09/13/89). Containers and Transportation Plan (First Report). Reference \#010.

Office of Civilian Radioactive Waste Management (05/01/91). Responses to the Comments on the Preliminary Designs for th:- From-Reactor Casks from EEI/UWASTE. Reference \#017.

Office of Civilian Radioactive Waste Management (05/01/91). Responses to the Comments on the Preliminary Designs for the From-Reactor Casks from Western Interstate Energy Board. Reference $\# 0$ s.s.

Office of Civilian Radioactive Waste Management (02/01/90). Cask Systems Development: BR-100 Rail / Barge Cask (OCRWM Backgrounder). Reference \#023.

Office of Civilian Radioactive Waste Management (02/01/90). Cask Systems Development: GA-4 \& GA-9 Truck Cask (OCRWM Backgrounder). Reference \#019.

Office of Civilian Radioactive Waste Management (02/01/90). Cask Systems Development: NACCTC Rail/Barge Cask (OCRWM Backgrounder). Reference \#022.

Office of Civilian Radioactive Waste Management (02/01/90). Cask Systems Development: NuPac 140-B Rail/Barge Cask (OCRWM Backgrounder). Reference \#021.

Office of Civilian Radioactive Waste Management (02/01/90). Cask Systems Development: Titan Truck Cask (OCRWM Backgrounder). Reference \#020.

Office of Civilian Radioactive Waste Management (01/01/87). Transportation Casks for Spent Nuclear Fuel and High-Level Radioactive Waste. Reference \#045.

Office of Civilian Radioactive Waste Management (02/14/86). Information Package for from Reactor Cask Program (Transportation Systems Acquisition Phase i Initiative). Reference \#007.

Pope, R.B. (12/04/90). Cask System Maintenance (Presentation to the OCRWM TCG Meeting, Albuquerque). Reference \#043.

Pope, R.B., M.J. Rennich, L.G. Medley, and C.R. Attaway (01/01/91). Cask System Maintenance in the Federal Waste Management System - A Feasibility Study and Update. Reference \#049.

Pope, Ronald B. (03/15/91). Cask System Maintenance - A Feasibility Study and Update (Presentation to the SSEB High-Level Radioactive Waste Committee, New Orleans). Reference \#024. 
Pope, Ronald B. (02/21/90). International Experience in Cask Design and Operations (Presentation before the Transportation Coordination Group, Lexington). Reference \#025.

Rennich, M.J., L.G. Medley, and C.R. Attaway (Martin Marietta) (01/01/91). Cask Maintenance Facility Feasibility Study Report. Reference \#012.

Sanders, Thomas L. (ed.) (10/01/89). Proceedings of a Workshop on the Use of Burnup Credit in Spent Fuel Transport Casks. Reference \#009.

Snedeker, David F. (12/01/90). Nuclear Waste Transportation Package Testing: A Review of Selected Programs in the United States and Abroad. Reference \#(015.

Vincent, John (12/03/90). The Utility Industry's View of the Status of OCRWM's Cask Systems Development Program (Presentation to OCRWM TCG Meeting, Albuquerque). Reference \#(2n:

Warrant, Marilyn M. (Sandia National Laboratories) (02/21/90). OCRWM Cask Technology Development and Testing Program (Presentation to the OCRWM Transportation Coordination Group Meeting, Lexington). Reference \#037.

Western Interstate Energy Board (03/14/89). Technical Briefing: Shipping Container Resnonse to Severe Highway and Railway Accident Conditions (Summary). Reference \#011.

Westinghouse Electric Corporation (05/01/90). Preliminary Design Report Executive Summary: Westinghouse TITAN Cask. Reference $\# 002$.

Westinghouse Electric Corporation Nuclear Services Division (04/01/90). TITAN Legal Weight Truck Cask Preliminary Design Report (Volume I). Reference \#035.

Westinghouse Electric Corporation Nuclear Services Division (C1/01/90). TITAN Legal Weight Truck Cask Preliminary Design Report (Volume II). Reference \#036.

Yates, Ken (02/21/90). Cask System A nalysis: Initiative I Cask Specification Study - Spent Fuel Cooling Time and Burnup (Presentation before the Transportation Coordination Group, Lexington). Reference \#(1)47.

\section{Emergency Response}

(12/(44/90). Section 180(c) Issues Presentations: Panel Discussion Period (Presentation before the Transportation Coordination Group Meeting, Albuquerque). Reference \#036.

(10/23/90). National Conference on Radiological Emergency Preparedness: Conference Report Narrative. Reference \#(037.

(09/(01/89). Illinois Nudear Safety Preparedness Act (Chapters 111.5, Paragraphs 4301-431()). Reference \#(030.

((07/01/89). Federal Roles for Emergency Assistance, Preparedness and Response (Overview). Reference \#032.

Allen, Gerald (Nebraska State Civil Defense Agency) (04/19/89). Radiological Emergencies Response Handbook. Reference \#019. 
Association of American Railroads (01/01/92). Hands-on Training for the Serious Responder: Hazardous Materials Training Transportation Test Center 1992 Catalog and Schedule. Reference $\#$ (149.

Becker, Victoria, Mary Fetter, and James Solyst (National Governors' Association) (01/01/89). Emergency Planning and Community Right-To-Know Act: A Status of State Actions - 1989.

Reference \#012.

Chemical Manufacturers Association (01/01/89). National Chemical Response \& Information Center: Annual Report 1988. Reference \#028.

Coburn, Nancy (03/16/90). Emergency Preparedness (Presentation to the Midwestern High-Level Radioactive Waste Transportation Committee). Reference \#026.

Federal Emergency Management Agency (09/01/89). Management Plan for Radiological Training Series. Reference \#010.

Federal Emergency Management Agency (05/01/89). Directory of Governors, State Officials and Adjutant Generals Responsible for Disaster Operations and Emergency Planning. Reference \#002.

Federal Emergency Management Agency (08/01/88). Guidance for Developing Stâte and Local Radiological Emergency Response Plans and Preparedness for Transportation Accicients. Reference \#011.

Federal Emergency Management Agency (01/01/91). Guidance for Developing State, Tribil and Local Radiological Emergency Response Planning and Preparedness for Transportation Arcidents. Reference \#024.

Federal Emergency Management Agency (01/01/89). Emergency Management Institut: Catalogue of Activities, 1989/89. Reference \#006.

Foster, Barbara (06/01/88). State and Federal Contacts for Highway Accident Information. Reference \#017.

Gage County Civil Defense Agency (07/01/89). Local Emergency Operations Plan: Beatrice, Nebraska, Gage County. Reference \#038.

General Accounting Office (05/01/89). Federal Training for First Responders to Highway and Railroad Incidents. Reference \#()01.

Holm, Judith (12/05/90). Review Models for Possible OCRWM Use (Presentation before the Transportation Coordination Group, Albuquerque). Reference \#033.

Illinois Department of Nuclear Safety, Division of Planning and Analysis. Illinois Medical Facilities Capable of Handling Contaminated and/or Irradiated Individuals. Reference \#(040.

Intertech Consultants, Inc. (06/01/89). Radiological Emergency Response in Small Communities: A Report on Capabilities and Constraints. Reference \#016.

MacDonald, Charles E. (U.S. Nuclear Regulatory Commission) (11/14/89). Indiana University Emergency Response Survey (Presentation to the SSEB Advisory Committee on Radioactive Waste Transportation, Atlanta). Reference \#029. 
Michigan Department of State Police, Emergency Management Division (08/01/89). Michigan Emergency Preparedness Plan. Reference \#(039.

Nebraska State Livil Defense Agency (01/12/87). Nebraska Radiological Emergency Response Plan for Non-Power Reactor Incidents. Reference \#018.

Nebraska State Civil Defense Agency (01/01/83). Nebraska Disaster and Civil Defense Act. Reference \#007.

Office of Environmental Restoration and Waste Management, U.S. Department of Energy (01/01/92). Emergency Management Program. Reference \#051.

Overview of the Federal Radiological Emergency Response Plan and the Role of the Department of Energy. Reference \#031.

Pacific States Agreement (0?/12/90). Mutual Aid Agreement for Accidents Involving Hazardous Materials and Radioactive Materials (Draft). Reference \#034.

Science Applications International Corporation (05/01/89). Emergency Preparedness for Transportation Incidents Involving Radioactive Materials. Reference \#009.

South Dakota Department of Military and Veterans Affairs, Division of Emergency and Disaster Services (09/01/87). South Dakota State Emergency Operations Plan. Reference \#041.

Southern States Energy Board (06/01/90). Southern States Radiological Emergency Response Laws and Regulations. Reference \#004.

Southern States Energy Board (04/01/90). Southern State Radiological Transportation Emergency Response Training Course Summary. Reference \#021.

Southern States Energy Board (04/01/90). The Southern Mutual Radiation Assistance !lan. Reference \#008.

Southern States Energy Board (11/01/88). Southern State Radiological Emergency Preparedness and Response Agencies. Reference \#022.

Southern States Energy Board (10/01/91). Radiological Transportation Emergency Response Training Course Funding and Timing in the Southern States. Reference \#047.

Southem States Energy Board (01/01/91). Radiological Transportation Emergency Response Training Course Funding and Timing in the Southern States (Draft). Reference \#044.

Southern States Energy Board (11/01/88). Mutual Assistance Agreements for Radiological Emergency Response. Reference \#013.

Southern States Energy Board (11/01/88). The Southern Mutual Radiation Assistance Plan. Reference \#014.

U.S. Department of Energy (04/01/91). Transportation Emergency Preparedness Program (TEPP): Strategy Plan. Reference \#050.

U.S. Department of Energy (02/01/89). Radioactive Material Transportation Emergency Response Orientation. Reference \#015. 
U.S. Department of Labor, Occupational Safety and Health Administration (01/01/89). Hazardous Waste and Emergency Response. Reference \#020.

U.S. Department of Transportation (RSPA) (01/01/87). Emergency Response Guidebook. Reference $\# 053$.

U.S. Nuclear Regulatory Commission (06/01/92). Emergency Response to a Highway Accident in Spri.gfield, Massachusetts, on December 16, 1991. Reference \#052.

U.S. Nuclear Regulatory Commission (08/01/89). State Cost Sharing of Training: A Task Force Report. Reference \#025.

U.S. Nuclear Regulatory Commission and the Federal E.mergency Management Agency (07/01/91). Post-emergency Response Resources Guide. Reference \#048.

U.S. Nuclear Regulatory Commiscion, Federal Emergency Management Agency (07/01/91). Lessons Learned From the Post-Emergency TABLETOP Exercise in Baton Rouge, Louisiana, on August 28 and September 18, 1990. Reference \#046.

Villardo, Frank J., Eric L. Mitter, James A. Palmer, Henry C. Briggs, and Julie Fesenmaier (Indiana University) (05/01/90). Survey of State and Tribal Emergency Response Capabilities for Radiological Transportation Incidents. Reference $\# 023$.

Western Interstate Energy Board (11/10/89). Timing of Emergency Response Trairing Under Section 180 of the Nuclear Waste Policy Amendments Act (Dr ftt). Reference $\# 003$.

Western Interstate Energy Board (08/01/88). Implementation Strategy for Section 180(c) of the 1987 Amendments to the Nuclear Waste Policy Act. Reference \#005.

Western Interstate Energy Board (01/30/91). Comments on DOE's Section 180(c) Training Strategy by the Western Interslate Energy Board's High-Level Radioactive Waste Committee. Reference \#035.

Western Interstate Energy Board (03/01/90). Timing of Emergency Response Training Under Section 180 of the Nuclear Waste Policy Amendments Act (Final). Reference \#045.

'Nestern Interstate Energy Board (06/09/89). Mutual Aid Among the Western States: Agreements Applicable to Transportation Accidents Involving Radioactive Materials. Reference \#027.

Wisconsin Department of Administration, Division of Emergency Government (08/01/83). State of Wisconsin Radiological Emergency Response Plan: Nuclear Power Plants (Volume I: State Response). Reference $\#() 42$.

Wisconsin Department of Administration, Division of Emergency Government (08/01/83). State of Wisconsin Radiological Emergency Response Plan: Nuclear Power Plants (Volurne II: Local Government Response). Reference \#043.

\section{Energy}

Bisconti, Ann S. (USCEA) (09/05/90). U.S. Public Opinion in a Changing Environment (Presentation at the Annual Symposium of the Uranium Institute, London). Reference \#064.

California Energy Commission (06/01/90). Energy Technology Status Report: Report Summary. Reference \#041. 
Denniston, Derek (Environmental and Energy Study Institute) (03/30/91). Energy Legislation Summary. Reference $\$ 049$.

Donaldson, D.M., and G.E. Betteridge (09/05/90). Potential Impact of the Greenhouse Effect on Electricity Supply (Presentation at the Annual Symposium of the Uranium Institute, London). Reference \#063.

Energy Information Administration. Annual Outlook for U.S. Electric Power 1989: Projections Through 2000 . Reference \#002.

Energy Information Administration (02/01/92). Energy Information Directory 194i. Reference \#067.

Energy Information Administration (03/01/91). Annual Energy Outlook 1991: With Projections to 2010. Rucrence \#044.

Energy Information Administration (10/\$1/89). U.S. Crude Oil, Natural Gas, and Natural Gas Liquids Reserves: 1988 Annual Report. Reference \#010.

Energy Information Administration (07/01/89). State Energy Price Projections for the Residential Sector 1989-1990. Reference \#005.

Energy Information Administration (06/23/89). Assurntiptions for the Annual Energy Outlook 1989. Reference \#024.

Energy Information Administration (09/01/88). State Energy Price Projections for the Resider cial Sector 1988-1989. Reference \#025.

Energy Information Administration (02/01/92). Electric Sales and Revenue 1990. Reference \#068.

Energy Information Administration $(05 / 01 / 91)$. U.S. Energy Industry Financial Developments: 1991, First Quarter. Reference \#048.

Energy Information Administration (06/01/90). An Analysis of Heating Fuel Market Behavior 198990. Reference \#020.

Energy Information Administration (02/13/90). Assumptions for the Annual Energy Outlook 1990. Reference \#(011.

Energy Information Administration (01/12/90). Annual Energy Outlook 1990: Long-term Projections to 2010 . Reference t012. $^{2}$.

Energy Information Administration (11/22/89). Coal Production 1988. Reference \#013.

Energy Information Administration (04/01/89). Regional Projections of End-Use Energy

Consumption and Prices Through 2000. Reference \#001.

Energy Information Administration (01/10/89). Annual Energy Outlook 1989: Long-term Projections. Reference \#023.

Energy Information Administration (01/01/89). Estimates of Biofuels Consumption in the United States during 1987. Reference \#009. 
Ciee, J.T., K.W. Tucker, L.A. Joo', D.V. Stewart, T. Alcom, and A. Tabereaux (08/01/89). Long-Term Testing and Evaluation of Cathode Components in a Commercial Aluminum Cell. Reference \#(22.

General Accounting Office (03/01/92). Energy Reports and Testimony: 1991. Reference \#066.

General Accounting Otfice (09/01/92). Options to Reduce Environmental and Other Costs of Gasoline Consumption. Reference \#070.

General Accounting Office (02/01/91). Evolution of DOE's Process for Developing a National Energy Strategy. Reference \#042.

General Accounting Office (09/01/90). Older Plants' Impact on Reliability and Air Quality. Reference \#031.

General Accounting Office (07/01/90). Energy: Bibliography of GAO Documents January 1986 December 1989. Reference \#028.

General Accounting Office (07/01/90). Impacts From Increased Use of Ethanol Blended Fuels. Reference \#029.

General Accounting Office (05/01/90). DOE's Allocation of Funds for Basic and Applied Research and Development. Refererıce \#033.

General Accounting Office (10/18/89). Perspectives on the Potential of Clean Coal Technologies to Reduce Emissions From Coal-Fired Power Plants. Reference \#061.

General Accounting Office (05/17/89). DOE's State Energy Conservation Grant Programs. Reference $\# 059$.

Illinois Department of Energy and Natural Resources (01/01/91). Illinois Statewide Electric Utility Plan: Optioning Resources for the Future, 1992-2012. Volume I: Executive Summary. Reference $\# 054$.

Illinois Department of Energy and Natural Resources (01/01/91). Illinois Statewide Electric Utility Plan: Optioning Resources for the Future, 1992-2012. Volume II: Main Report. Reference \#055.

Illinois Department of Energy and Natural Resources (01/01/91). Illinois Statewide Electric Utility Plan: Optior ing Resources for the Future, 1992-2012. Volume III: Appendices. Reference \#056.

Interstate Oil Compact Commission (12/03/89). The Interstate Oil \& Gas Compact \& Committee Bulletin: The 1989 Annual Meeting (Tulsa, Oklahoma). Reference \#017.

Interstate Oil Compact Commission (06/18/89). The Interstate Oil \& Gas Compact \& Committee Bulletin: The 1989 Midyear Meeting (Reno, Nevada). Reference \#007.

Jones, Peter (09/05/90). Comparative Economics of the Main Electricity Sources (The Uranium Institute Annual Symposium). Reference \#051.

Lee, William S. (09/01/90). Energy for Our Globe's People. Reference \#069.

Minnesota Department of Public Service, Energy Division (01/01/90). Minnesota Energy Data Book: Energy Trends from 1960 through 1988. Reference \#014.

Nebraska Energy Office. Nebraska Energy Statistics 1960-1988. Reference \#026. 
North Dakota Office of Intergovernmental Assistance (05/01/89). North Dakota Energy Supply and Consumption (Statistical Summary). Reference \#015.

Ray, Dixie Lee (08/01/90). Greenhouse Earth. Reference \#065.

Science Concepts, Inc. (02/01/90). Energy Use and Global 'Narming: Background and Perspective. Reference \#050.

Temple, Barker \& Sloane, Inc. (01/22/90). Economic Analysis of S. 1630 "The Clean Air Act Amendments of 1989": Air toxics, NOx and $\mathrm{SO}_{2}$ Provisions for Electric Utilities. Reference \#)16.

U.S. Department of Energy (02/01/92). National Energy Strategy: Powerful Ideas for America, One Year Later. Reference \#062.

U.S. Department of Energy (02/15/90). Advanced Fossil Energy Technologies. Reference \#008.

U.S. Department of Energy (01/01/89). The Secretary's Annual Report to Congress 1988-1989.

Reference \#036.

Watkins, James D. (02/01/91). United States Depurtment of Energy Posture Statement and Fiscal Year 1992 Budget Overview. Reference $\# 030$.

Wisconsin Energy Bureau (07/01/90). Wisconsin Energy Statistics-1990. Reference \#038.

\section{Environment}

Blix, Hans (05/29/91). Nuclear Power and the Environment (Presentation at the Seminar "Atomic Energy in Our Cianging World," Budapest, May 29, 1991). Reference \#005.

Envirorimental and Energy Study Institute (05/01/91). Partnership for Sustainable Development: A New U.S. Agenda for International Development and Environmental Security. Reference \#003.

General Accounting Office (04/01/92). Better Management for DOE's Technology Development Program. Reference \#004.

General Accounting Office (09/01/92). Unresolved Issues May Hamper Success of EPA's Proposed Emissions Program. Reference \#009.

O'Connor, Philip R. (05/14/91). Implications of the Clean Air Act on Nuclear Power (Presentation to the Nuclear Power Assembly). Reference \#(0)6.

Portney, Paul R. Economics and the Clean Air Act. Reference \#002.

U.S. Department of Energy, Nevada Field Office. Desert Tortoise Conservation: Procedures for Conserving Desert Tortoises on the Nevada Test Site. Reference i. .07 .

U.S. Environmental Protection Agency. Fact Sheets on Clear Air Act Amendments of 1990. Reference \#001. 


\section{Hazardous Waste}

(06/05/89). Subcommittee on Surface Transportation Field Hearings on Transportation of Hazardous Materials: Summary of Subject Matter (Denver, Colorado). Reference \#005.

(01/01/89). Hazardous Waste in Interstate Commerce: Minimizing the Problem After City of Philadelphia v. New Jersey. Reference \#011.

101st U.S. Congress. Hazardous Materials Transportation Uniform Safety Act of 1990. Reference $\# 007$.

Cungressional Record-Senate (10/26/90). Hazardous Materials Transportation Uniform Safety Act. Reference \#004.

Evolution and Development of the Hazardous Materials Transportation Act (P.L. 93-633) As Applied to the Regulation of Radioactive Materials. Reference \#008.

General Accounting Office (06/01/92). Advantages of and Barriers to Reducing the Use of Toxic Chemicals. Reference \#016.

General Accounting Office (04/01/92). Impediments Delay Timely Closing and Cleanup of Facilities. Reference \#015.

General Accounting Office (12/01/87). DOE Needs to Better Identify Funds for Hazardous Waste Compliance. Reference \#013.

National Response Team (03/01/87). Hazardous Materials Emergency Planning Guide. Reference $\# 001$.

Office of Technology Assessment (07/01/86). Transportation of Hazardous Materials. Reference \#(010.

Reed, James B. (10/01/91). Warning: Hazardous Materials on Board. Reference \#014.

Spirer, Patricia $(03 / 14 / 91)$. Introduction to the Hazardous Materials Transportation Uniform Safety Act of 1990 (Presentation to SSEB Meeting, New Orleans). Reference \#012.

U.S. Department of Transportation (08/31/92). Transportation of Hazardous Materials; Highway Routing; Proposed Rules. Reference \#017.

U.S. Department of Transportation and FEMA (07/01/86). Report to the Congress on Hazardous Materials Training, Planning and Preparedness. Reference \#009.

U.S. Environmental Protection Agency (12/01/90). Enhancing State Superfund Capabilities: A NineState Study. Reference \#003.

U.S. Environmental Protection Agency, Office of Solid Waste and Emergency Response (06/01/87). The Hazardous Waste System. Reference \#002.

Western Interstate Energy Board (12/05/90). Hazardous Materials Transportation Act Amendments: Analysis by the Western Interstate Energy Board. Reference \#006. 


\section{Interim Storage}

Electric Power Research Institute (04/01/87). NUHOMS Spent-Fuel Storage Demonstration: Program Overview. Reference \#008.

General Accounting Office (02/01/88). Information on the Reracking of the Diablo Canyon Spent Fuel Storage Pools. Reference \#011.

General Accounting Office (06/01/90). Information on DOE's Interim Transuranic Waste Storage Facilities. Reference \#005.

Gormley, O.P. (01/01/82). The Role of Dry Storage as a Means to Meet National Storage Needs in the United Statf.s. Reference \#010.

Johnson, E.R., and J.A. McBride (01/01/82). Technical and Economic Assessment of Alternative Dry Storage Methods. Reference $\# 009$.

Minnesota Environmental Quality Board (Cupit \& Sabel) (11/30/90). Environmental Impact Statement: Prairie Island Independent Spent Fuel Storage Installation (Draft). Reference \#002.

Office of Civilian Radioactive Waste Management (08/01/88). Initial Version: Dry Cask Storage Study. Reference \#001.

Roberts, John P. (01/17/90). Dry Spent Fuel Storage Licensing at Reactor Sites (Paper for Institute of Nuclear Materials Management Spent Fuel Management Seminar VII). Reference \#004.

Sturz, Fritz (Nuclear Regulatory Commission) (05/30/91). Onsite Dry Storage of Spent Nuclear Fuel (Presentation before the Midwestern High-level Radioactive Waste Transportation Committee). Reference \#003.

U.S. Department of Energy (02/01/89). Final Version Dry Cask Storage Study. Reference \#(007.

U.S. Nuclear Regulatory Commission (08/22/84). The Commission's Decision in the Matter of Rulemaking on the Storage and Disposal of Nuclear Waste (Waste Confidence Rulemaking). Reference $\#(0) 6$.

\section{Low-Level Waste}

General Accounting Office (10/14/92). Nebraska Low-Level Waste: Supplemental Information. Reference \#012.

General Accounting Office (08/01/92). New York's Adherence to Site Selection Procedures is Unclear. Reference \#008.

General Accounting Office (01/01/92). Nuclear Waste: Slow Progress Developing Low-Level I rdioactive Waste Disposal Facilities. Reference \#001.

General Accounting Office (07/01/91). Extensive Process to Site Low-Level Waste Disposal Facility in Nebraska. Reference \#002.

Midwest Interstate Low-Level Radioactive Waste Compact Commission (08/01/92). Annual Report for the Period from July 1, 1991, to June 30, 1992. Reference \#010. 
Northeast Interstate Low-Level Radioactive Waste Commission (03/01/92). 1991 Annual Report. Reference \#(0)7.

Office of Technology Assessment (11/01/89). Partnerships Under Pressure: Managing Commercial Low-Level Radioactive Waste (Summary). Reference \#005.

U.S. Nuclear Regulatory Commission. Below Regulatory Concern: A Guide to the Nuclear Regulatory Commission's Policy on the Exemption of Very Low-level Radioactive Materials, Wastes and Practices. Reference \#003.

U.S. Nuclear Regulatory Commission (07/03/90). Below Regulatory Concern: Policy Statement. Reference \#004.

U.S. Supreme Court (06/23/92). New York v. United States et al. Reference \#011.

Vanags, U. (for the Maine Low-Level Radioactive Waste Authority) (05/01/92). A Study of Radioactive Wastes. Reference \#OG

Zermer, Melanie (Legislative Research) (08/26/87). State Land Use Laws aind the Siting of Locally Unwanted Land Uses. Reference \#006.

\section{Miscellaneous}

(05/10/89). Federal Travel Regulations. Reference \#005.

American Nuclear Society (01/01/92). World Directory of Radwaste Managers. Reference \#055.

Burns, William, Paul Slovic, Roger Kasperson, Jeanne Kasperson, Ortwin Renn, and Srinivas Emani (09/01/90). Social Amplification of Risk: An Empirical Study. Reference \#052.

Conference of Radiation Control Program Directors, Inc. (10/01/92). Directory of Stite Agencies Involved with the Transportation of Radioactive Material. Reference \#060.

Conference of Radiation Control Program Directors, Inc. (10/01/91). Directory of State Agencies Involved with the Transportation of Radioactive Material (with notes on their statutory authority and regulations). Reference \#044.

Fabian, Thecla (ed.) (01/01/91). Directory of Federal, State and Regional Radioactive Waste Management Offices. Reference \#042.

General Accounting Office (07/01/92). Entertainment Costs Under DOE's Uranium Enrichment Production Contract. Reference \#058.

Intergraph (Ed John, Sales Representative) (11/01/08). Intergraph Information Package: Tracking Technologies. Reference \#008.

Loren, Gideon, and Naomi Klein (10/02/91). Bias Against Negative Studies in Newspaper Reports of Medical Research. Reference \#056.

Midwestern Office of the Council of State Governments (11/01/91). Midwestern High-Level Radioactive Waste Committee Meeting Briefing Materials (St. Louis). Reference \#045. 
Midwestern Office of the Council of State Governments (05/30/91). Midwestern High-Level Radioactive Waste Committee Meeting Briefing Materials (Chicago). Reference \#(1)24.

Midwestern Office of the Council of State Governments (11/15/90)). Midwestern High-Level Radioactive Waste Committee Meeting Briefing Materials (Minneapolis). Reference \#023.

Midwestern Office of the Council of State Governments (03/16/90)). Midw 'stern High-Level Radioactive Waste Committee Meeting Briefing Materials (Chicago). Reference \#022.

National Conference of State Legislalures (04/12/91). NCSL High-Level Radioactive Waste/Hazardous Materials Transportation Task Force Meeting Transcript (Lincoln, Nebraska). Reference \#029.

Nuclear Waste Technical Review Board (03/10/92). Meeting of the Panel on Transportation and Systems. Reference \#050.

Nuclear Waste Technical Review Board (10/08/91). Full Board Meeting Transcripts (Las Vegas, October 8-10, 1991). Reference \#(49.

Nuclear Waste Technical Review Board (10/01/91). Nuclear Waste Technical Review Board, Transportation and Systems Panel Meeting Minutes (September 25-26, 1991). Reference \#046.

Nuclear Waste Technical Review Board (08/15/91). United States Nuclear Waste Technical Review Board Panel on Transportation \& Systems Public Hearing (Denver, August 15, 1991). Reference \#040.

Nuclear Waste Technical Review Board (05/20/91). United States Nuclear Waste Technical Review Board: Meeting of the Panel on Risk and Performance Assessme. it (Meeting Minutes). Reference $\# 036$.

Office of Civilian Radioactive Waste Management (12/04/90). Transportation Coordination Group Meeting Minutes (Albuquerque). Reference \#033.

Office of Civilian Radioactive Waste Management $(02 / 21 / 9())$. Highlights of the Transportation Coordination uroup Meeting (Lexington, Kentucky). Reference \#034.

Office of Civilian Radioactive Waste Management (07/25/89). Transportation Coordination Group Meeting Minutes (Chicago). Reference \#032.

Office of the Nuclear Waste Negotiator (06/05/91). Operating Procedures; Intent to Coordinate on Feasibility Assessment Grants; and Intent to Negotiate Agreements. Reference \#()37.

Selin, Ivan (07/09/91). Message from Chairman Ivan Selin (Goals for the Future of the NRC). Reference \#(143.

Southern States Energy Board ((03/14/90)). Advisory Committee on Radioactive Materials Transportation Final Agenda \& Briefing Book (New Orleans). Reference \#017.

Southern States Energy Board (10/09/91). Southern States Energy Board Advisory Committee on Radioactive Materials Transp'station: Briefing Materials (Gatlinburg, TN, October 9-10, 1991). Reference $\# 048$.

Southern States Energy Board (07/01/90). TRU Waste Transportation Working Group Proceedings (Williamsburg, VA, June 21, 1990 ). Reference \#(012. 
Southern States Energy Board (12/01/89). Southern States Energy Board Advisory Committee on Radioactive Materials Transportation, Proceedings (Atlanta, November 14-15, 1989). Reference \#011.

Southern States Energy Board (10/11/89). Southem States Energy Board Advisory Committee on Radioactive Waste Transportation Briefing Book (Atlanta, November 14-15, 1989). Reference \#010.

Southern States Energy Board (04/01/89). Southern States Energy Board Advisory Committee on Radioactive Materials Transportation Briefing Book (Atlanta, April 12-13, 1989). Reference \#013.

Southern States Energy Board (06/16/92). Transuranic (TRL) Waste Transportation Working Group Meeting Minutes and Proceedings (San Antonio, June 16, 1992). Reference \#057.

Southern States Energy Board (06/26/91). SSEB Transuranic (TRU) Waste Transportation Working Group Final Agenda \& Briefing Book (Chicago). Reference \#030.

Southern States Energy Board (06/26/91). SSEB Transuranic (TRU) Waste Transportation Working Group: Meeting Minutes \& Proceedings (Chicago). Reference \#035.

Southern States Energy Board (03/14/91). Advisory Committee on Radioactive Materials Transportation Meeting Minutes \& Proceedings (New Orleans). Reference \#018.

Southern States Energy Boarci (06/19/90). Advisory Committee on Radioactive Materials Transportation: Meeting Minuies \& Prociedings (Williamsburg, VA, June 19-20, 1990). Reference \#019.

Southern States Energy Board (06/19/90). High-Level Radioactive Waste Transportation DEl/SSEB Cooperative A.greement Overview/Status of Deliverables. Reference \#006.

Southern States Energy Board (05/01/90). Southern States Energy Board Advisory Committee on Radioactive Materials Transportation Briefing Book (Williamsburg, VA, June 19-20, 1990). Reference \#014.

Southern States Energy Board (05/01/90). TRU Waste Transportation Working Briefing Book (Williamsburg, VA, June 19-20, 1990). Reference \#009.

Southern States Energy Board (09/01/89). Legislative Digest 1989. Reference \#007.

U.S. Congress (10/17/86). Emergency Planning and Community Right-to-Know Act of 1986. Reference \#054.

U.S. Department of Energy (04/20/92). Education Programs Catalog 1992. Reference \#051.

U.S. Department of Energy (06/12/92). Transportation Emergency Preparedness External Coordination (TEC) Working Group Meeting Summary (New Orleans, March 30-April 1, 1992). Reference \#059.

U.S. Department of Energy, Office of the Controller (02/01/88). Budget Highlights: FY 1989. Reference \#001.

U.S. Nuclear Regulatory Commission (07/08/91). Final Revisions to 10 CFR Parts 170 and 171 on License, Inspection and Annual Fees. Reference \#039.

U.S. Nuclear Regulatory Commission (05/21/91). Standards for Protection Against Radiation; Final Rule. Reference \#038. 
Western Interstate Energy Bo ird (02/20/90). Western Interstate Energy Board High-Level Waste Committee Meeting (Denver, March 5-6, 1990). Reference \#016.

Western Interstate Energy Board (11/08/89). Western Interstate Energy Board High Level Waste Committee Meeting (Salt Lake City, November 20-21, 1989). Reference \#015.

Western Interstate Energy Board (04/16/92). High-Level Radioactive Waste Committee Meeting (Las Vegas, April 16-17, 1992). Reference \#053.

Western Interstate Energy Board (10/01/91). High-Level Waste Committee Meeting Briefing Materials (October 23-24, 1991). Reference \#047.

Western Interstate Energy Board (05/13/91). Briefing Book for High-Level Waste Committee Meeting (Denver). Reference \#021.

Western Interstate Energy Board (05/13/91). Western Interstate Energy Board High-Level Waste Committee Meeting Final Minutes (Denver). Reference \#031.

Western Interstate Energy Board (12/05/90). Briefing Material for Western Interstate Energy Board High Level Waste Committee Meeting (Albuquerque). Reference \#026.

Western Interstate Energy Board (12/05/90). Final Committee Meeting Minutes for WIEB HighLevel Waste Committee Meeting (Albuquerque). Reference \#028.

Western Interstate Energy Board (03/12/90). Minutes from March 5-6 Meeting of the WIEB HighLevel Waste Committee Meeting. Reference \#027.

Western Interstate Energy Board (11/20/89). Draft Minutes from Western Interstate Energy Board High-Level Waste Committee Meeting (Salt Lake City). Reference \#025.

\section{MRS}

Brentlinger, L.A., S. Gupta, A.M. Plummer, L.A. Smith, and S. Tzemos (Battelle Nuclear Systems Group) (01/01/90). Supplement to MRS Systems Study, Task F: Transportation Impacts of a Monitored Retrievable Storage Facility. Reference \#004.

Brentlinger, L.A., S. Gupta, A.M. Plummer, L.A. Smith, and S. Tzemos (Battelle Nuclear Systems Group) (05/01/89). MRS Systems Study, Task F: Transportation Impacts of a Monitored Retrievable Storage Facility. Reference \#003.

General Accounting Office (09/24/91). Operation of Monitored Retrievable Storage Facility is Unlikely by 1998 . Reference \#012.

Jackson, Mark E. (Battelle Nuclear Systems Group) (05/01/89). Monitored Retrievable Storage System Study, Task H: Licensing. Reference \#006.

Monitored Retrievable Storage Review Commission (11/01/89). Nuclear Waste: Is There A Need for Federal Interim Storage? (Executive Summary). Reference \#010.

Office of Civilian Radioactive Waste Management (06/01/89). The DOE Position on the MRS Facility. Reference \#002. 
Office of Civilian Radioactive Waste Management (07/01/91). A Monitored Retrievable Storage Facility: Technical Background Information. Reference \#011.

Office of Civilian Radioactive Waste Management (01/01/91). Spent Fuel Storage at the Monitored Retrievable Storage Facility. Reference \#013.

Office of Civilian Radioactive Waste Management (06/01/89). MRS System Study Summary Report. Reference \#001.

Office of Civilian Radioactive Waste Management (01/01/89). Role of the Monitored Retrievable Storage Facility in an Integrated Waste Management System. Reference \#009.

Parker, Frank L. (11/20/89). Comments on the Report of the Monitored Retrievable Storage Review Commission. Reference \#005.

Reed, James B. (12/01/90). Monitored Retrievable Storage of High-Level Radioactive Waste: Routing Implications and Emergency Response to Transportation Accidents. Reference \#008.

Smith, Ben L. (C.overnor's Planning Office, State of Tennessee) (11/14/89). A Critical Analysis of the Report of the Monitored Retrievable Storage Commission. Reference \#007.

Trebules, Victor (10/01 /92). Monitored Retrievable Storage Technologies, Operations, and Status of Siting Activities (Presentation before WIEB HLW Committee, Denver, September 30-October 1, 1992). Reference \#C 15.

Wood, T.W., S.M. Short, M.G. INoodruff, M.K. Altenhofen, and C.A. MacKay (PNL) (04/01/89). MRS Systems Study Task G Report: The Role and Functions of Surface Storage of Radioactive Material in the Federal Waste Management System. Reference \#014.

\section{Nuclear Energy}

American Nuclear Energy Council (07/16/90). Response of the American Nuclear Energy Council to the Department of Energy's Interim Report on the Development of A National Energy Strategy. Reference \#021.

Bisconti, Ann S. (USCEA) (03/07/90). Public Opinion in the United States and Canada: Five Reasons for Cautious Optimism. Reference \#048.

Council on Scientific Affairs, American Medical Association (11/17/89). Medical Perspective on Nuclear Power. Reference \#050.

Davis, A. Bert, and Cynthia D. Peterson (U.S. Nuclear Regulatory Commission) (03/01/90). Industry Perceptions of the Impact of the U.S. Nuclear Regulatory Commission on Nuclear Power Plant Activities (Draft Report). Reference \#009.

Dey, M. (U.S. Nuclear Regulatory Commission) (04/01/90). Maintenance Approaches and Practices in Selected Foreign Nuclear Power Programs and other U.S. Industries: Review and Lessons Learned. Reference $\# 010$.

Edelson, Edward (01/01/88). The Journalist's Guide to Nuclear Energy. Reference \#012.

Energy Information Administration (10/01/91). World Nuclear Fuel Cycle Requirements 1991. Reference \#055. 
Energy Information Administration (05/01/91). An Analysis of Nuclear Plant Operating Costs: A 1991 Update. Reference \#036.

Energy Information Administration (09/10/89). World Nuclear Fuel Cycle Requirements 1989. Reference \#001.

EPRI Journal (10/01/90). Nuclear Plants: Life After 40. Reference \#032.

Erickson, Terrell (01/01/88). Civilian Nuclear Programs: The United States, France, and Japan. Reference \#005.

Finger, Harold B. (USCEA) (08/01/89). The Need for Nuclear Energy (Statement at a National Energy Strategy Hearing, U.S. DOE). Reference \#049.

General Accounting Office (09/01/90). Shippingport Decommissioning: How Applicable are the Lessons Learned? Reference \#015.

General Accounting Office (05/01/90). U.S. Electricity Needs and DOE's Civilian Reactor Development Program. Reference $\# 035$.

General Accounting Office (09/30/89). Usefulness of Space Power Research to Ground-Based Nuclear Reactor Systems. Reference \#034.

General Accounting Office (05/01/89). NRC's Decommissioning Procedures and Criteria Need to be Strengthened. Reference \#004.

General Accounting Office (03/01/89). Effect of Conversion of Washington Nuclear Plant No.1 on Debt and Electric Rates. Reference \#033.

General Accounting Office (03/01/89). What Can Be Done to Revive the Nuclear Option? Reference \#003.

Ghosh, Palash R. (11/01/90). Latest Studies do not Support Link Between Cancer Mortality and Radiation Discharges. Reference \#052.

Golay, Michael W., and Neil E. Todreas (04/01/90). Advanced Light-Water Reactors. Reference \#024.

Greenwald, John (04/29/91). Time to Choose. Reference \#047.

Hohenemser, Christoph, Robert L. Goble, and Paul Slovic (01/01/90). Institutional Aspects of the Future Development of Nuclear Power. Reference \#057.

Institute of Nuclear Power Operators (03/01/91). Performance Indicators for the U.S. Nuclear Utility Industry: 1990. Reference \#043.

Jablon, Seymour, Zdenek Hrubec, John D. Boice, Jr., and B.J. Stone (U.S. Department of Health and Human Services) (07/01/90). Cancer in Populations Living Near Nuclear Facilities (Volume 1 Report and Summary). Reference \#018.

Lord Marshall Kt CBE FRS (03/06/90). Radioactive Materials and Radioactive Waste (Address at the Institution of Lighting Engineers). Reference \#051. 
Management Analysis Company (for the American Nuclear Energy Council) (07/01/90). Power Plant Ordering Schedule Required to Ensure Reliable Electric Service. Reference \#016.

Management Information Services, Inc. (for U.S. Council for Energy A wareness) (04/01/91). Right on the Money: Costs, Benefits, and Results of Federal Support for Nuclear Energy. Reference \#042.

Management Information Services, Inc., and Management Analysis Company (for the U.S. Council For Energy Awareness) (04/01/91). Right on the Money: Costs, Benefits, and Results of Federal Support for Nuclear Energy. Reference \#014.

Moore, W. Henson (U.S. Deputy Secretary of Energy) (09/17/90). Restoring the Nuclear Option: Prospects for Progress (Address before the 34th General Conference of the IAEA, Vienna). Reference \#046.

Nealey, Stanley M. (01/01/90). Nuclear Power Development: Prospects in the 1990s. Reference \#022.

Nuclear Power Oversight Committee (11/01/91). Strategic Plan for Building New Nuclear Power Plants: First Annual Update. Reference \#044.

Nuclear Power Oversight Committee (11/01/90). A Perfect Match: Nuclear Energy and the National Energy Strategy: A Position Paper by the Nuclear Power Oversight Committee. Reference \#026.

Presidential Commission on Catastrophic Nuclear Acciderics (08/01/90). Report to the Congress (Volume I). Reference \#019.

Presidential Commission on Catastrophic Nuclear Accidents (08/01/90). Report to the Congress (Volume II). Reference \#020.

Rhodes, Joseph, Jr. (11/13/90). Nuclear Power, Waste Disposal, New Reactor Technology: Pyramids Underground (Presentation at Annual NARUC Convention, Orlando). Reference \#(27.

Runyon, Cheryl (03/01/89). A Summary of the Price-Anderson Act of 1988. Reference \#008.

Science Concepts, Inc. (01/01/90). Reducing Airborne Emissions with Nuclear Electricity. Reference \#029.

Science Concepts, Inc. (for the U.S. Council for Energy A wareness) (07/01/89). The Impact of the Wor!d's Electric Generation Sector and Nuclear Power on OPEC Oil Markets. Reference \#017.

Shrader-Frechette, K.S. (01/01/80). Nuclear Technology. Reference \#059.

Sklar, Steven V. (American Nuclear Energy Council) (04/01/90). State Government Annual Report for 1989. Reference \#011.

Slovic, Paul (01/01/91). Perception of Risk and the Future of Nuclear Power. Reference \#056.

Slovic, Paul (01/01/90). Perception of Risk from Radiation. Reference \#058.

Smith, Douglas J. (03/01/90). Nuclear Suppliers Prepare for the Next Generation of Orders. Reference \#025.

Smith, Sherwood H., Jr. (12/01/91). A Case for Reviving the Nuclear Option. Reference \#054. 
U.S. Council for Energy Awareness (09/01/91). Electricity from Nuclear Energy: 1991-1992 Edition. Reference \#(153.

U.S. Council for Energy Awareness (07/01/90). Electricity from Nuclear Energy: 1990-91 Edition. Reference \#(123.

U.S. Council for Energy Awareness (05/31/90)). USCEA 1989 International Reactor Survey. Reference \#030.

U.S. Council for Energy Awareness (04/01/90). Health Effects Associated with Living Near Various Nuclear Facilities, Background Radiation, and Uranium Mining. Reference \#028.

U.S. Department of Energy (08/01/84). The Nuclear Fuel Cycle. Reference \#002.

U.S. Nuclear Regulatory Commission. The Price-Anderson System. Reference \#006.

U.S. Nuclear Regulatory Commission (06/01/90). Loss of Vital AC Power and the Residual Heat Removal System during Mid-Loop Operations at Vogtle Unit 1 on March 20, 1990. Reference \#013.

U.S. Nuclear Regulatory Commission, Office of Nuclear Reactor Regulation (08/01/91).

Environmental Standard Review Plan for the review of license renewal applications for Nuclear Power Plants (Draft Report for Comment). Reference \#040.

U.S. Nuclear Regulatory Commission, Office of Nuclear Regulatory Research (08/01/91). Generic Environmental Impact Statement for License Renewal of Nuclear Plants: Main Report (Draft Report for Comment). Reference \#038.

U.S. Nuclear Regulatory Commission, Office of Nuclear Regulatory Research (08/01/91). Generic Environmental Impact Statement for License Renewal of Nuclear Plants: Appendices (Draft Report for Comment). Reference \#037.

U.S. Nuclear Regulatory Commission, Office of Nuclear Regulatory Research (08/01/91). Guidance for the Preparation of Supplemental Environmental Reports in Suppori of an Application to Renew a Nuclear Power Station Operating License. Reference \#041.

U.S. Nuclear Regulatory Commission, Office of Nuclear Regulatory Research (08/01/91). Regulatory Analysis of Proposed Amendments to Regulations Concerning the Environmental Review for Renewal of Nuclear Power Plant Operating Licenses. Reference \#039.

Washington State Institute for Public Policy (12/01/87). Nuclear Futures: What Does Our Experience with the Nuclear Waste Policy Act Suggest About the Future of Nuclear Power in the Unites States? Reference \#007.

Weinberg, Alvin M. (12/01/89). Engineering in an Age of Anxiety. Reference \#045.

\section{NWPA}

(08/14/91). Memo of Understanding between the Office of the U.S. Nuclear Waste Negotiator and the U.S. Nuclear Regulatory Commission (SP-91-111). Reference \#019.

(01/01/86). Standard Contract for Disposal of Spent Nuclear Fuel and/or High-Level Radioactive Waste (10 CFR Part 961). Reference \#012. 
General Accounting Office (06/01/92). Status of Actions to Improve DOE User-Fee Assessments. Reference \#(023.

General Accounting Office (05/01/92). Questionable Uses of Program Funds at Lawrence Livermore Laboratory. Reference $\# 024$.

General Accounting Office (04/01/90). Quarterly Report as of December 31, 1989. Reference \#027.

General Accounting Office (12/01/89). Quarterly Report on DOE's Nuclear Waste Program as of June 30, 1989. Reference \#026.

General Accounting Office (11/22/88). Comments on the Department of Energy's Implemeniation of the Nuclear Waste Policy Act. Reference \#039.

General Accounting Office (09/01/88). Fourth Annual Report on DOE's Nuclear Waste Program. Reference \#028.

General Accounting Office (08/01/88). Quarterly Report on DOE's Nuclear Waste Program as of June 30, 1988. Reference \#031.

General Accounting Office (05/01/88). Quarterly Report on DOE's Nuclear Waste Program as of March 31, 1988. Reference \#030.

General Accounting Office (02/01/88). Quarterly Report on DOE's Nuclear Waste Program as of December 31, 1987. Reference \#029.

General Accounting Office (02/01/91). Quarterly Report as of March 31, 1990. Reference \#007.

General Accounting Office (07/01/90). DOE Needs to Ensure Nevada's Conformance with Grant Requirements. Reference \#008.

General Accounting Office (03/01/90). Quarterly Report As of September 30, 1989. Reference \#003.

General Accounting Office (08/01/89). Quarterly Report as of March 31, 1989. Reference \#002.

General Accounting Office (02/01/89). DOE's Method for Assigning Defense Waste Disposal Costs Complies with NWPA. Reference \#017.

General Accounting Office $(08 / 01 / 88)$. Problems Associated with DOE's Inactive Waste Sites. Reference \#032.

General Accounting Office (02/01/87). Institutional Relations Under the Nuclear Waste Policy Act of 1982. Reference \#001.

Leroy, David (Nuclear Waste Negotiator) (05/03/91). Letter to Governors and Indian Tribal Leaders from the Office of the Nuclear Waste Negotiator. Reference \#018.

Leroy, David H. (12/31/90). Office of the United States Nuclear Waste Negotiator: Commencement of Operations (A Summary of Activities and Progress 9/90 to 12/90). Reference $\# 015$.

Nuclear Waste Technical Review Board (06/01/92). Fifth Report to the U.S. Congress and the U.S. Secretary of Energy. Reference \#037. 
Nuclear Waste Technical Review Board (12/01/91). Fourth Report to the U.S. Congress and the U.S. Secretary of Energy. Reference \#036.

Nuclear Waste Technical Review Board (05/01/91). Third Report to the U.S. Congress and the U.S. Secretary of Energy. Reference \#035.

Nuclear Waste Technical Review Board (11/01/90). Second Report to the U.S. Congress and the U.S. Secretary of Energy. Reference \#034.

Nuclear Waste Technical Review Board (03/01/90). First Report to the U.S. Congress and the U.S. Secretary of Energy. Reference \#033.

Office of Civilian Radioactive Waste Management (06/01/89). Federal Agencies Involved in the Implementation of the Nuclear Waste Policy Act of 1982. Reference \#013.

Office of Civilian Radioactive Waste Management. Reprints from Public Laws: P.L. 97-425, Title V of P.L. 100-203, P.L. 100-507. Reference $\$ 006$.

Office of Civilian Radioactive Waste Management (11/01/90). Nuclear Waste Fund Fee Adequacy: An Assessment. Reference \#009.

Office of Civilian Radioactive Waste Management (08/01/85). Managing the Nation's Nuclear Waste: Overview - Nuclear Waste Policy Act. Reference \#016.

Office of the Nuclear Waste Negotiator (05/03/91). Basic Information Package From the Office of the Nuclear Waste Negotiator. Reference \#010.

Office of the Nuclear Waste Negotiator (04/30/91). Moving Beyond the Headlines: Negotiated Nuclear Facility Siting in the 90 's (Remarks of David H. Leroy at HLRWM Conference and Exposition, Nevada). Reference \#011.

Reed, J.R., and K.A. Mahoney (NCSL) (05/01/92). Federal Training Assistance for the Transportation of Spent Fuel. Reference \#025.

Runyon, Cheryl (06/01/88). Federal Agencies Involved with the High-Level Waste Disposal Program. Reference \#004.

Runyon, Cheryl (05/01/88). Nuclear Waste Policy Amendments Act of 1987. Reference \#005.

Rusche, Ben C. (01/01/86). Status of the United States' High-Level Nuclear Waste Disposal Program. Reference \#038.

Sharp, J., S. Grady, and G. Harrison (12/01/91). Research Paper to Support the Development of Section 180(c) Policy Options (Draft). Reference \#022.

Viebrock, J.M. and N. Mote (Nuclear Assurance Corporation) (05/01/92). Facility Interface Capability Assessment (FICA) Summary Report. Reference \#020.

Viebrock, J.M., and N. Mote (02/01/92). Near-Site Transportation Infrastructure Project Final Report (Draft). Reference \#021. 


\section{OCRWM}

Bartlett, John W. (Director) (08/11/91). Nuclear Waste Management Decisions in the $1990 \mathrm{ss.}$

Reference $\#$ ()30.

Battelle Mernorial Institute (05/01/88). Analysis of Institutional Issues and Lessons Learned From Recent Spent Nuclear Fuel Shipping Campaigns (1983-1987). Reference \#009.

Conner, Carl W. (Office of Civilian Radioactive Waste Management) (04/01/90). Trends in Waste Management Program Costs: An Evolution of Estimating Methods and Results. Reference \#018.

Easterling, J. Bennett (07/29/91). U.S. Radioactive Waste Management: Status of the Program. Reference \#031.

General Accounting Office (09/01/92). Better Information Resources Management Needed to Accomplish Missions. Reference \#034.

Kouts, Christopher (U.S. Department of Energy, OCRWM) (03/16/90). Office of Civilian Radioactive Waste Management Transportation Program (Presentation to the Midwestern High -Level Radioactive Waste Committee). Reference \#022.

Nuclear Waste Technical Review Board (12/13/89). Environment and Public Health Panel (First Report). Reference \#016.

OCRWM CSDP Independent Management Review Group (IMRG) (08/24/82). First Report. Reference \#035.

Office of Civilian Radioactive Waste Disposal Program (05/01/89). Analysis of the Total System Life Cycle Cost for the Civilian Radioactive Waste Management Program. Reference \#017.

Office of Civilian Radioactive Waste Management. Guide to OCRWM Transportation Program Responsibilities. Reference \#025.

Office of Civilian Radioactive Waste Management (01/01/92). Draft Strategy for OCRWM to Provide Training Assistance to State, Tribal, and Local Governments. Reference \#033.

Office of Civilian Radioactive Waste Management (12/01/91). Annual Capacity Report. Reference $\# 032$.

Office of Civilian Radioactive Waste Management (11/26/90). Strategy to Provide Training Assistance as Required by Section 180(c) of the Nuclear Waste Policy Act (As Amended) Preliminary Draft. Reference \#020.

Office of Civilian Radioactive Waste Management (08/01/90). Management Systems Improvement Strategy. Reference \#024.

Office of Civilian Radioactive Waste Management (11/01/89). Report to Congress on Reassessment of the Civilian Radioactive Waste Management Program. Reference \#005.

Office of Civilian Radioactive Waste Management (01/01/86). Program Management System Manual. Reference \#014.

Office of Civilian Radioactive Waste Management (10/01/85). Quality Assurance Management Policies and Requirements. Reference \#001. 
Office of Civilian Radioactive Waste Management (06/01/85). Mission Plan for the Civilian Radioactive Waste Management Program (Volume 1: Parts I \& II). Reference \#(15.

Office of Civilian Radioactive Waste Management (12/01/90). Annual Report to Congress. Reference $\# 027$.

Office of Civilian Radioactive Waste Management (05/01/90). Major Federal Regulations Which Affect the Civilian Radioactive Waste Management Program. Reference \#026.

Office of Civilian Radioactive Waste Management (12/01/89). Annual Report to Congress. Reference \#008.

Office of Civilian Radioactive Waste Management (08/01/89). OCRWM Publications Catalog. Reference \#019.

Office of Civilian Radioactive Waste Management (06/01/87). OCRWM Mission Plan Amendment with Comments on the Draft Amendment and Responses to the Comments. Reference \#003.

Office of Civilian Radioactive Waste Management (04/01/87). Annual Report To Congress. Reference \#007.

Office of Civilian Radioactive Waste Management (04/01/87). Public Participation in the Development of the Transportation Institutional Plan. Reference \#023.

Office of Civilian Radioactive Wastı Management (01/01/87). Draft Mission Plan Amendment. Reference \#004.

Office of Civilian Radioactive Waste Management (08/01/86). Information Services Directory. Reference \#028.

Office of Civilian Radioactive Waste Management (06/01/86). Public Information Guidelines. Reference \#029.

Office of Civilian Radioactive Waste Management (03/01/86). Annual Report to Congress. Reference \#006.

Office of Civilian Radioactive Waste Management (11/01/85). Internal Guidelines for Interactions with Communities and Local Governments. Reference $\#(0) 2$.

Roberts, Jeffrey B. (02/14/91). Update on OCRWM Transportation Program (Presentation at SSEB Meeting, New Orleans). Reference \#021.

Runyon, Cheryl (10/01/88). A Summary of the Department of Energy's Draft 1988 Mission Plan Amendment. Reference \#012.

Runyon, Cheryl (12/01/87). Acronyms Associated with the High-Level Radioactive Waste Disposal Program. Reference \#013.

Runyon, Cheryl (11/01/87). Department of Energy High-Level Waste Repository Coordinating Groups. Reference \#010. 


\section{Radioactive Waste}

American Society of Civil Engineers and American Nuclear Society (04/28/91). High-Level Radioactive Waste Management: Proceedings of the Second Annual International Conference (Volume 1). Reference \#019.

American Society of Civil Engineers and American Nuclear Society, Inc. (04/28/91). High-Level Radioactive Waste Management: Proceedings of the Second Annual International Conference (Volume 2). Reference \#020.

American Society of Civil Engineers and American Nuclear Society, Publishers (04/08/90). HighLevel Radioactive Waste Management (Volume 1): Proceedings of the International Topical Meeting. Reference \#015.

American Society of Civil Engineers and American Nuclear Society, Publishers (04/08/90). HighLevel Radioactive Waste Management (Volume 2): Proceedings of the International Topical Meeting. Reference \#016.

American Society of Civil Engineers and the American Nuclear Society $(04 / 12 / 92)$. High-Level Radioactive Waste Management: Proceedings of the Third International Conference (Volume 1). Reference \#047.

American Society of Civil Engineers and the American Nuclear Society (04/12/92). High-Level Radioactive Waste Management: Proceedings of the Third International Conference (Volume 2). Reference \#048.

Bisconti, Ann S. (USCEA) (07/01/91). Public Attitudes about Nuclear Waste. Reference \#035.

Bisconti, Ann S., and Livingston, Robert L. (U.S. Council on Energy Awareness) (01/01/92). Communicating with the Public about Radiation. Reference \#037.

Church, Foster (04/01/90). Can Nevada Keep America's Sizzling Nuclear Waste Out of Its Backyard? Reference \#039.

General Accounting Office (07/01/92). Improvements Needed in Monitoring Contaminants in Hanford Soils. Reference \#045.

General Accounting Office (06/01/92). Defense Waste Processing Facility - Cust, Schedule, and Technical Issues. Reference \#(046.

General Accounting Office (09/01/88). Supplementary Information on Problems at DOE's Inactive Waste Sites. Reference \#049.

General Accounting Office (08/05/91). Hanford Single-Shell Tank Leaks Greater Than Estimated. Reference \#036.

General Accounting Office (06/12/91). Pretreatment Modifications at DOE Hanford's B Plant Should Be Stopped. Reference \#034.

General Accounting Office (04/01/91). Problems and Delays with Characterizing Hanford's SingleShell Tank Waste. Reference \#029.

General Accounting Office (06/01/90). Changes Needed in DOE User-Fee Assessments to Avoid Funding Shortfall. Reference $\# 032$. 
General Accounting Office (11/01/89). DOE's Program to Prepare High-Level Radioactive Waste for Final Disposal. Reference \#(33.

Illinois Department of Nuclear Safety. Radiological Response-Abilities. Reference \#006.

Kammerer, Carlton. Nuclear Regulatory Commission's State Agreements Program. Reference \#(23.

Krauskopf, Konrad B. (09/14/90). Disposal of High-Level Nuclear Waste: Is It Possible? Reference \#041.

League of Women Voters Education Fund (01/01/85). The Nuclear Waste Primer: A Handbook for Citizens. Reference \#018.

Lutze, Werner, and Rodney C. Ewing, Editors (01/01/ 99$)$. Scientific Basis for Nuclear Waste Management XII. Reference \#017.

Marshall, Eliot (02/22/91). The Geopolitics of Nuclear Waste. Reference \#040.

Moore, R. Scott, and Karl J. Notz (04/28/91). Tools for Spent Fuel Characterization Assembly Classes and Fuel Designs (Presentation to the International HLRWM Conference, Las Vegas). Reference $\# 027$.

Moore, Taylor (07/01/90). The Hard Road to Nuclear Waste Disposal. Reference \#042.

Murray, Raymond L. (01/01/89). Understanding Radioactive Waste (Third Edition). Reference \#022.

National Conference of State Legislators (02/01/85). State Legislation on Spent Fuel. Reference \#030.

National Conference of State Legislatures (12/01/91). NCSL Official Policy on Radioactive Waste Management. Reference \#044.

National Research Council (01/01/90). Rethinking High-Level Radioactive Waste Disposal: A Position Statement of the Board on Radioactive Waste Management. Reference \#021.

Nuclear Energy Agency of the OECD. Nuclear Waste Management: France. Reference \#028.

Oak Ridge National Laboratory (11/01/89). Integrated Date Base for 1989: Spent Fuel and Radioactive Waste Inventories, Projections, and Characteristics. Reference \#014.

OCDE, OECD, U.S. Department of Energy (11/01/88). Managing the Nation's Nuclear Waste (United States of America). Reference \#012.

Office of Civilian Radioactive Waste Management. Managing the Nation's Nuclear Waste: Factsheet Series. Reference \#007.

Office of Civilian Radioactive Waste Management (05/01/90). Radiation and High-Level Nuclear Waste. Reference \#024.

Office of Civilian Radioactive Waste Management (03/01/86). Managing the Nation's Nuclear Waste. Reference \#002.

Office of Civilian Radioactive Waste Management (05/01/90). Characteristics and Inventories of Nuclear Waste. Reference \#025. 
Office of Civilian Radioactive Waste Management (06/01/89). Geographic Distribution of HighLevel Nuclear Waste. Reference \#026.

Runyon, Cheryl (06/01/88). Selected European High-Level Radioactive Waste Disposal Program. Reference \#011.

Russ, George D., Jr. (A tomic Industrial Forum, Inc.) (06/01/84). Nuclear Waste Disposal: Closing the Circle. Reference \#013.

Schneider, K.J., W.A. Ross, R.I. Smith, P.M. Daling, R.B. Grinde, C.J. Hosteck, R.W. Peterson, D.L. Stiles, S. Weakley, J.R. Young (11/01/87). Analysis of Radiation Doses from Operation of Postulated Commercial Spent Fuel Transportation Systems. Reference \#001.

Shrader-Frechette, K.S. (01/01/80). Nuclear Wastes and the Argument from Ignorance. Reference $\# 051$.

Slovic, Paul, James H. Flynn, and Mark Layman (12/13/91). Perceived Risk, Trust, and the Politics of Nuclear Waste. Reference \#038.

U.S. Department of Energy (12/01/91). Spent Fuel Storage Requirements 1991-2040. Reference \#050.

U.S. Department of Transportation. Illinois Spent Nuclear Fuel Transportation. Reference \#004.

U.S. Department of Transportation (11/01/84). A Guide for the Inspection of Radioactive Material Shipments by Motor Vehicle or at Freight Facilities. Reference \#003.

U.S. Department of Transportation (06/01/83). A Review of the Department of Transportation Regulations for Transportation of Radioactive Materials. Reference \#005.

U.S. Nuclear Regulatory Commission (S. Droggitis, Editor) (12/01/87). The U.S. Nuclear Regulatory Commission Program with State and Local Governments and Indian Tribes. Reference \#008.

\section{Rail/Highway}

(09/01/90). Near Site Transportation Infrastructure Assessment. Reference \#022.

Carlson, R.W., and L.E. Fischer (LLNL) (06/01/92). A Highway Accident Involving Unirradiated Nuclear Fuel in Springfield, Massachusetts, on December 16, 1991. Reference \#027.

Conlon, Peter (Association of American Railroads) (05/20/92). Railroad Industry Perspective on the Transportation of Nuclear Waste (Presentation before the Transportation Coordination Group, Phoenix, May 20-21, 1992). Reference \#024.

DOT Inconsistency Rulings - Transportation of Radioactive Materials. Reference \#005.

Economic Analysis Division, U.S. Department of Transportation (11/01/89). Review of the Selection of the Rail Route for Shipping Three Mile Island Debris. Reference \#023.

Economides, Elaine. Highway Routing of Spent Nuclear Fuel: The DOT Rule and Its Impacts. Reference \#017.

Foster, Barbara, and James B. Reed (04/01/89). Nuclear Regulatory Commission Modal Study of Severe Highway and Train Accidents. Reference \#008. 
General Accounting Office (06/01/90). A Comparison of Federal and State Highway Laws. Reference \#011.

General Accounting Office (06/01/90). States Benefit From Block Grant Flexibility. Reference \#012.

General Accounting Office (11/01/89). Passive Restraints Needed to Make Light Trucks Safer. Reference \#010.

Goldberg, Steven C. (01/01/89). State Nuclear Transportation Routing Laws. Reference \#020.

Holm, Judith (03/16/90). Highway Routing (Presentation to the Midwestern High-Level Radioactive Waste Committee). Reference \#014.

Jordan, Julie, and Barbara Foster (08/01/86). Rail Transport of Spent Fuel and High-Level Waste. Reference \#009.

McClure, Thomas A., Lee Ann Brentlinger, Vincent J. Drago, and David C. Kerr (Battelle Memorial Institute) (01/01/88). Considerations in Rail Routing of Radioactive Materials, with Emphasis on the Relationship Between Track Class and Train Accidents. Reference \#001.

National Conference of State Legislators, High-Level Radioactive Waste/Hazardous Materials Transportation Task Force (09/05/91). Report on Modal Selection for Spent Fuel Transportation (Draft). Reference \#026.

Office of Civilian Radioactive Waste Management (01/01/90). Preliminary Rail Access Study. Reference \#006.

Office of Civilian Radioactive Waste Management (04/01/89). Nevada Highway Routing Study. Reference \#007.

Office of Civilian Radioactive Waste Management (01/01/87). Transportation Routing Issues Related to the Shipment of High-Level Nuclear Waste. Reference \#019.

Southern States Energy Board (08/01/89). Lessons Learned by Southern States in Designating Alternative Routes. Reference \#003.

Southern States Energy Board (02/01/89). Southern States' Routing Agency Report. Reference $\# 002$.

U.S. Department of Transportation (01/01/89). Guidelines for Selecting Preferred Highway Routes for Highway Route Controlled Quantity Shipments of Radioactive Materials. Reference \#004.

U.S. Department of Transportation (01/19/81). Radioactive Materials: Routing and Driver Training and Routing Exemptions. Reference \#018.

U.S. Department of Transportation, Research and Special Programs Administration (08/01/92). Guidelines for Selecting Preferred Highway Routes for Highway Route Controlled Quantity Shipments of Radioactive Materials (Update). Reference \#028.

Watros, Gary (U.S. Department of Transportation) (03/24/90). Review of the Selection of the Rail Route for Shipping Three Mile Island Debris. Reference \#016.

Wentz, Christopher J. (05/20/92). Lessons Learned: State of New Mexico's Experience in the WIPP Highway Route Designation Process. Reference \#025. 
Western Interstate Energy Board (09/01/92). Utility Rail Shipments in the Western Region. Reference \#029.

Western Interstate Energy Board (06/01/91). Rail Primer: Legal, Technical and Business Aspects of Rail Transportation (Revised). Reference \#021.

Western Interstate Energy Board (11/08/89). Summary of Technical Briefing: Shipping Container Response to Severe Highway and Railway Accident Conditions. Reference \#015.

\section{Repository}

Blackford, Michael E., and Keith I. McConnell (04/01/91). Staff Technical Position on Investigations to Identify Fault Displacement and Seismic Hazards at a Geologic Repository. Reference \#029.

Clamp, Alice (09/01/91). Of Mountains and Molehills. Reference \#030.

Cook, B.J., J.L. Emel, and R.E. Kasperson (01/01/90). Organizing and Managing Radioactive Waste Disposal as an Experiment. Reference \#042.

England-Joseph, Judy (04/18/91). DOE Expenditures on the Yucca Mountain Project (Statement Before Senate Subcommittee on Nuclear Regulation). Reference \#028.

Flynn, James (04/15/92). How Not to Sell a Nuclear Waste Dump. Reference \#045.

Flynn, James H., C.K. Mertz, and Paul Slovic (05/01/91). Yucca Mountain Socioeconomic Project: The 1991 Nevada State Telephone Survey: Key Findings. Reference \#034.

Flynn, James H., Paul Slovic, C.K. Mertz, and James Toma (09/01/90). Evaluations of Yucca Mountain Survey Findings About the Attitudes, Opinions, and Evaluations of Nuclear Waste Disposal and Yucca Mountain, Nevada. Reference \#036.

Flynn, James, Roger Kasperson, Howard Kunreuther, and Paul Slovic (01/01/92). Time to Rethink Nuclear Waste Storage. Reference \#046.

Freudenburg, William (09/01/91). Organizational Management of Long-Term Risks: Implications for Risk and Safety in the Transportation of Nuclear Wastes. Reference \#037.

General Accounting Office (05/01/92). DOE's Repository Site Investigations, a Long and Difficult Task. Reference \#032.

Inhaber, Herbert (06/01/91). A Market-based Solution to the Problem of Nuclear and Toxic Waste Disposal. Reference \#031.

Kunreuther, H., D. Easterling, W. Desvousges, and P. Slovic (07/01/90). Public Attitudes Toward Siting a High-Level Nuclear Waste Repository in Nevada. Reference \#041.

Kunreuther, H., W.H. Desvousges, and P. Slovic (10/01/88). Nevada's Predicament. Reference \#043.

Kunreuther, Howard, Doug Easterling, and Paul Kleindorfer (09/01/88). The Convention Planning Process: Potential Impact of a High-Level Nuclear Waste Repository in Nevada. Reference \#039. 
Kunreuther, Howard, Paul Slovic, Joanne Nigg, and William H. Desvousges $(09 / 01 / 87)$. Yucca Mountain Socioeconomic Project Report on the 1987 Risk Perception Telephone Surveys. Reference \#033.

Mountain West Research (12/01/89). Yucca Mountain Socioeconomic Project Preliminary Findings: 1989 Nevada State Telephone Survey. Reference \#035.

Nuclear Waste Technical Review Board (04/16/91). Natural and Archaeological Analogues Meeting Transcripts: Volume I (Reno, Nevada). Reference \#017.

Nuclear Waste Technical Review Board $(04 / 17 / 91)$. Natural and Archaeological Analogues Meeting Transcripts: Volume II (Reno, Nevada). Reference \#018.

Nuclear Waste Technical Review Board (03/26/91). Quality Assurance and Structural Geology and Geoengineering Joint Panel Meeting Transcript (Dallas). Reference \#015.

Nuclear Waste Technical Review Board (03/06/91). NWTRB Structural Geology \& Geoengineering and Hydrology \& Geochemistry Joint Panel Meeting Transcripts (Denver). Reference \#009.

Nuclear Waste Technical Review Board (03/01/91). Structural Geology \& Geoengineering Panel Meeting: Volcanic Hazards and Vulnerabilities (Tucson). Reference \#016.

Nuclear Waste Technical Review Board (11/01/90). Quality Assurance Panel Meeting Transcripts Volume I (Arlington, Virginia). Reference \#013.

Nuclear Waste Technical Review Board (11/02/90). Quality Assurance Panel Meeting Transcripts Volume II (Arlington, Virginia). Reference \#014.

Nuclear Waste Technical Review Board (10/15/90). Environment \& Public Health Public Meeting Transcripts Volume I (Reno). Reference \#020.

Nuclear Waste Technical Review Board (10/16/89). Environment \& Public Health Public Meeting Transcripts Volume II (Reno). Reference \#021.

Nuclear Waste Technical Review Board (10/10/90). Nuclear Waste Technical Review Board Meeting on Waste Confidence Proceeding and EPRI/EEl High-Level Waste Repository Methodology.

Reference \#010.

Nuclear Waste Technical Review Board (08/29/90). Engineer('d Barrier System Panel Meeting Transcript Volume I (Pleasanton, California). Reference \#01

Nuclear Waste Technical Review Board (08/29/90). Engineered Barrier System Panel Meeting Transcript Volume II (Pleasanton, California). Reference \#012.

Nuclear Waste Technical Review Board (01/09/90). Hydrology and Geochemistry Panel (First Report). Reference \#005.

Nuclear Waste Technical Review Board (09/13/89). Risk and Performance Analysis Panel (First Report). Reference \#007.

Nuclear Waste Technical Review Board (09/13/89). Structural Geology and Geoengineering Panel (First Report). Reference \#006. 
Office of Civilian Radioactive Waste Management. Progress Report on the Scientific Investigation Program for the Nevada Yucca Mountain Site: Number 2 (October 1, 1989 to March 31, 1990).

Reference \#019.

Office of Civilian Radioactive Waste Management (05/01/90). Activities During the Site Characterization Phase of the Geologic Repository Program. Reference \#023.

Office of Civilian Radioactive Waste Management (05/01/90). Addressing Concerns About Water Through Repository Siting and Design. Reference \#026.

Office of Civilian Radioactive Waste Management (05/01/90). Performance Assessment Under the Geologic Repository Program. Reference \#022.

Office of Civilian Radioactive Waste Management (05/01/90). Quality Assurance for Nuclear Waste Repositories. Reference \#027.

Office of Civilian Radioactive Waste Management (05/01/90). The Multiple Barrier System of Geologic Disposal of Spent Nuclear Fuel and High-Level Radioactive Waste. Reference \#024.

Office of Civilian Radioactive Waste Management (01/01/89). Site Characterization Plan Publir. Handbook. Reference \#001.

Office of Civilian Radioactive Waste Management (12/01/88). Site Chararterization Plan Overviev: Yucca Mountain Site, Nevada Research and Develojme ! Area, Nevada. Reference $\$ 002$.

Office of Civilian Radioactive Waste Manazement (02/01/90). Progress Report on the Scientific Investigation Program for the Nevada Yucca Mountain Site: Number $i(9 / 15 / 88$ to 4/15/89 and $4 / 16 / 89$ to $9 / 30 / 89$. Reference \#004.

Office of Civilian Radioactive Waste Management (06/07/ $/ 8^{\mathrm{H}}$. Studies of Alternative Methods of Nuclear Waste Disposal. Reference \#025.

Richards, M.D. (USCEA) i04/01/92). Siting Industrial Facilः 'ies: Lessons from the Sociai Science Literature. Reference \#044.

Schaefer, Jame (07/0: /88). State Opposition to Federal Nuclear Waste Repository Siting: A Case Studv of Wisconsin 1976-1988. Reference ${ }^{4} \cup 03$.

Slovic, P., M. Layman, and j.H. Flynn (04/01/91). Lessons from Yucca Mountain. Reference \#040.

Slovic, Paul, Mark Layman, Nancy N. Kraus, James Chalmers, Gail Gesell, and James Flynn $(07 / 01 / 89)$. Perceived Risk, Stigma, and Potential Economic Impacts of a High-Level Nuclear Waste Repository in Nevada. Reference \#038.

U.S. Department of Energy (02/01/90). Yucca Mountain Project Technical Status Report. Reference $\# 008$.

\section{Transportation}

AASHTO Task Force on Truck Size and Weight Regulation (07/10/89). Proposed Uniform Permitting Procedures and Overweight Vehicle for Truck Transport of Spent Nuclear Fuel. Reference \#044. 
Abkowitz, Mark D., Susan B. Abkowitz, and Mark Lepofsky (Battelle Nuclear Systems Group) $(04 / 01 / 89)$. Analysis of Human Factors Effects on the Safety of Transporting Radioactive Waste Materials. Reference \#018.

Ardila-Coulson, Maria V. (for the Nevada Department of Transportation) (12/01/89). The Statewide Radioactive Materials Transportation Plan (Phase II). Reference \#020.

Ardila-Coulson, Maria V. (for the Nevada Department of Transportation) (04/01/88). Nuclear Materials Transportation Investigation (Phase I). Reference \#024.

Battelle Memorial Institute (05/01/90). Quarterly Radioactive Materials Transportation Legal Developments Report. Reference \#027.

Battelle Memorial Institute (10/01/89). Compendium of Federal and State Radioactive Materials Transportation Laws and Regulations: Transportation Legislative Database (TLDB). Reference \#031.

Battelle Niemorial Institute (08/01/89). Transportation Newsclips Content and Geographic Analysis (April-June 1989). Reference \#011.

Battelle Memorial Institute (02/01/90). Quarterly Radioactive Materials Transportation Legal Developments Report. Reference \#030.

Battelle Memorial Institute (11/01/89). Quarterly Radioactive Materials Transportation Legal Developments Report. Reference \#029.

Battelle Memorial Institute (09/01/89). Annual Radioactive Materials Transportation Legal Developments Report. Reference \#009.

Battelle Memorial Institute (03/01/86). Overweight Truck Shipments to Nuclear Waste Repositories: Legal, Political, Administrative, and Operational Considerations (Technical Report). Reference \#010.

B st, Ralph E. (12/04/90). Waste Transportation System Requirements Resulting from Implementing ihe Standard Disposal Contract (Presentation before Transportation Coordination Group, Albuquarque). Reference \#055.

Binney, Stephen E. (01/01/91). Summary Response of Key Individuals about the Transport of Radioartive Waste from Hanford through Oregon: A Pre-Survey. Reference \#083.

Binney, Stephen E., and Robert G. Mason (01/01/91). Summary Response of Key Individuals about the Transport of Radioactive Waste from Hanford through Oregon: A Pre-survey. Reference \#087.

Brentlinger, L.A., P.L. Hofmann, and R.W. Peterson (Battelle Nuclear Systems Group) (08/01/89). Comparative Analyses of Spent Nuclear Fuel Transport Modal Options: Transport Options Under Existing Site Constraints. Reference \$021.

Commercial Vehicle Safety Alliance (09/01/91). Recommended National Procedures for the Safety Inspection of Commercial Highway Vehicles Transporting TRU, Spent Fuel, and HLW (Draft). Reference \#100.

Commercial Vehicle Safety Alliance. CVSA Pilot Study Summary. Reference \#050.

Conroy, Klimas, Pope (03/15/91). Operational Planning for the OCRWM Transportation System (Presentation to the SSEB High-Level Radioactive Waste Committee, New Orleans). Reference \#042. 
Conroy, Michael (12/04/90). Transportation System Requirements (Presentation before the Transportation Coordination Group, Albuquerque). Reference \#(148.

Danese, Larry (12/05/90). OCRWM Observation Activities of Ongoing Shipping Activities and SiteSpecific Servicing Plans (Presentation to Transportation Coordination Group, Albuquerque). Reference \#047.

Foster, Barbara (04/01/88). Inspection Procedures for Spent Nuclear Fuel and High-Level Radioactive Waste Truck Shipments. Reference \#015.

Foster, Barbara (03/01/88). U.S. Department of Transportation Inconsistency Rulings. Reference \#022.

Freudenburg, William R. (05/01/91). Human and Social Factors in the Transportation of Nuclear Wastes. Reference \#064.

General Accounting Office (08/01/87). Shipping, 5.:maged Fuel From Three Mile Island to Idaho. Reference $\# 095$.

General Accounting Office (03/01/90). States' Progress in Testing and Licensing Commercial Drivers. Reference \#014.

General Accounting Office (09/01/88). DOE Needs to Take Further Actions to Ensure Safe Transportation of Radioactive Materials. Reference $\# 070$.

Glickman, Theodore S., and Dominic Golding (04/01/91). For a Few Dollars More: Public Trust and the Case for Transporting Nuclear Waste in Dedicated Trains. Reference \#069.

Golding, Dominic, and Allen White (12/01/90). Guidelines on the Scope, Content, and Use of Comprehensive Risk Assessment in the Management of High-Level Nuclear Waste Transportation. Reference \#065.

Grassmeier, Katie (07/25/89). Yucca Mountain :'roject Transportation Status (Presented to Transportation Coordination Group Meeting). Reference \#037.

Halstead, R.J., and R. di Bartolo (01/07/90). State of Nevada Nuclear Waste Transportation Risk Studies (Presentation at the Transportation Research Board's 69th Annual Meeting, Washington). Reference \#045.

Halstead, R.J., R.R. Souleyrette, and R. di Bartolo. Transportation Access to Yucca Mountain: Critical Issues. Reference \#033.

Holm, Judith (11/14/90). Commercial Vehicle Safety Alliance Pilot Study (Presentation before the Midwestern High-level Radioactive Waste Transportation Committee, Minneapolis). Reference \#058.

Klimas, Michael (03/15/91). Near Site Transportation Infrastructure Assessment: Presentation before the SSEB High-Level Radioactive Waste Committee, New Orleans). Reference \#(43.

Klimas, Michael (12/04/90). Transportation Operational Planning Requirements and Description (Presentation before Transportation Coordination Group, Albuquerque). Reference \#053.

Klimas, Michael (11/14/90). Operational Planning: Reactor/Transportation Interface (Presentation before the Midwestern High-level Radioactive Waste Transportation Committee, Minneapolis). Reference \#059. 
Kouts, Christopher (12/04/90). Update on OCRWM Transportation Program (Presentation before Iransportation Coordination Group, Albuquerque). Reference \#062.

Kouts, Christopher A. (05/30/91). Update on OCRWM Transportation Program. Reference \#074.

MacGregor, Donald, Paul Slovic, Robert G. Mason, and John Detwiller (01/21/91). Transport of Radioactive Waste Through Oregon: Results of a Statewide Survey. Reference \#081.

MacGregor, Donald, Paul Slovic, Robert G. Mason, and John Detwiller (01/21/91). Transport of Radioactive Waste Through Oregon: Results of a Statewide Survey. Reference \#085.

McClure, J.D., and A. Tyron-Hopko (03/01/86). Radioactive Material (RAM) Transportation Accident/Incident Analysis. Reference \#005.

Midwestern Office of the Council of State Governments (05/01/91). Midwestern High-Level Radioactive Waste Transportation Primer. Reference \#038.

Mote, Nigel (Nuclear Assurance Corporation) (11/20/89). Facility Interface Capability Assessment (FICA) Project and Near-Site Transportation Infrastructure (NSTI) Project. Reference \#046.

National Governors' Association and the National Conference of State Legislatures (06/18/92). Alliance Phase One Subgroup Reports (Alliance for Uniform Hazmat Transportation Procedures). Reference \#097.

Nuclear Assurance Corporation (12/01/90). Commercial Spent Nuclear Fuel Shipments in the United States, 1964-1987. Reference \#036.

Nuclear Waste Technical Review Board (03/14/91). N'WTRB Transportation \& Systems Panel Meeting Transcripts (Albuquerque, March 14-15, 1991). Reference \#032.

Nuclear Waste Technical Review Board (11/19/90). NWTRB Transportation \& Systems Panel Public Hearing Transcripts (Reno, November 19, 1990). Refarence \#034.

Nuclear Waste Technical Review Board (11/19/90). Transportation and Systems Panel Public Hearing Transcripts (Reno). Reference \#057.

Nuclear Waste Technical Review Board (10/22/90). Transportation and Systems Panel Meeting Transcripts (Washington, D.C.). Reference \#056.

Office of Civilian Radioactive Waste Disposal (03/01/86). Transporting Spent Nuclear Fuel: An Overview. Reference $\# 004$.

Office of Civilian Radioactive Waste Management (04/01/87). Transportation Institutional Plan (Executive Summary). Reference \#028.

Office of Civilian Radioactive Waste Management (09/01/85). Draft Transportation Institutional Plan. Reference \#006.

Office of Civilian Radioactive Waste Management (05/01/90). Shipments of Spent Nuclear Fuel in Support of Nuclear Waste Policy Act Research and Development Programs. Reference \#060.

Office of Civilian Radioactive Waste Management (07/01/88). OCRWM Transportation Program Reference: Glossary, Acronym List, Bibliography. Reference \#026. 
Office of Civilian Radioactive Waste Management (08/01/86). Transportation Institutional Plan. Reference \#007.

Office of Civilian Radioactive Waste Management (01/01/86). Transportation Business Plan. Reference \#003.

Oregon Hanford Advisory Cornmittee (12/01/§8). Findings, Conclusions, and Recommendations on the Transport of Plutonium-Contaminated Nuclear Weapons Wastes through Oregon. Reference $\# 090$.

Pope, R.B. (12/04/90). Overview of Current Operations Planning Activities for the Federal Waste Management System (Presentation before the Transportation Coordination Grouf, Albuquerque). Reference \#052.

Pope, Ronald B. (03/06/90). International Spent Fuel Transport Programs: A Presentation on International Experience in Transporting Spent Nuclear Fuel. Reference \#061.

Reed, James B. (02/01/90). Tracking Technologies for Radioactive Waste Shipments. Reference \#025.

Reed, James, and Mara A. Cohen (05/01/91). Jurisdiction over Nuclear Waste Transportation on Indian Tribal Lands: State-Tribal Relationships. Reference \#035.

Resnikoff, Marvin (12/01/90). Probabilistic Risk Assessment and Nuclear Waste Transportation: A Case Study of the Use of RADTRAN in the 1986 Environmental Assessment for Yucca Mountain. Reference \#066.

Roland, Robert A. (Chemical Manufacturers Association) (02/02/92). Statement on Interstate Transportation and Disposal of Hazardous Waste (Presentation before the National Governors' Association). Reference \#088.

Rothman, Rob (12/05/90). Facility Interface Capability Assessment (Presentation before the Transportation Coordination Group, Albuquerque). Reference \#054.

Sattler, Lisa (Midwestern Office of the Council of State Governments) (10/01/92). Handbook of High-Level Radioactive Waste Transportation. Reference \#096.

Science Applications International Corporation (07/01/91). Historical Overview of Domestic Spent Fuel Shipments-Update. Reference \#063.

Shafer, Rebecca L. (NCSL) (07/01/92). Risk Assessment and Communication: Techniques for Managing the Transport of Nuclear Spent Fuel and High-Level Radioactive Waste. Reference \#091.

Sharp, Jerry, Steve Grady, and Glen Harrison (12/01/91). Research Paper to Support the Development of Section 180(c) Policy Options (Draft). Reference \#089.

Simmons, Dale (01/01/91). Personal Values and Public Perspectives on Highway Transport of Radioactive Wastes: A Summary of Significant Findings. Reference \#082.

Simmons, Dale (01/01/91). Personal Values and Public Perspectives on Highway Transport of Radioactive Wastes: A Summary of Significant Findings. Reference \#086.

Souleyrette, Reginald R., II, Shashi K. Sathisan, and Russell di Bartolo (05/31/91). Yucca Mountain Transportation Routes: Preliminary Characterization and Risk Analysis. Volume I: Research Report. Reference \#067. 
Souleyrette, Reginald R., Il, Shashi K. Sathisan, and Russell di Bartolo (05/31/91). Yucca Mountain Transportation Routes: Preliminary Characterization and Risk Analysis. Volume Il: Figures and Volume III: Technical Appendices. Reference \#()68.

South Dakota Department of Transportation (09/30/92). Transportation Improvement Program: 1993-1997. Reference \#099.

Southern States Energy Board (03/01/92). Spent Fuel and High-Level Radioactive Waste Transportation Report. Reference \#080.

Southern States Energy Board (03/01/92). Transportation Infrastructure Upgrades in the South. Reference \#079.

Southern States Energy Board (03/01/92). An Examination of the Hazardous Materials Transportation Uniform Safety Act (HMTUSA): A Southern Perspective. Reference \#078.

Southern States Energy Board (11/01/89). Spent Fuel and High-Level Radioactive Waste Transportation Report. Reference \#039.

Southern States Energy Board (07/01/87). Spent Nuclear Fuel and High-Level Radioactive Waste Transportation Primer. Reference \#051.

Transportation Operations Project Office, Oak Ridge National Laboratory (06/30/91). Transportation Communication Network Data Base: Alphabetical Listing. Reference \#071.

Transportation Operations Project Office, Oak Ridge National Laboratory (06/30/91). Transportation Communication Network Data Base: Categorical Listing. Reference \#072.

Tri-State Motor Transit Company (01/01/88). Radioactive Materials Transportation Manual: Specialized Service to Protect our Environment. Reference \#017.

Tuler, Seth, Roger E. Kasperson, and Samuel Ratick (Clark University) (06/01/88). The Effects of Human Reliability in the Transportation of Spent Nuclear Fuel. Reference \#084.

U.S. Department of Energy (07/01/92). Transportation Assessment and Integration (TRAIN). Reference \#092.

U.S. Department of Energy. Radioactive Material Shipping Regulations. Reference \#016.

U.S. Department of Energy. Transporting Uranium Hexafluoride. Reference \#012.

U.S. Department of Energy (11/06/91). Transportation Assessment and Integration (TRAIN): Draft. Reference \#077.

U.S. Department of Energy (08/01/91). Transportation Outreach Program Plan. Reference \#076.

U.S. Department of Energy (08/01/89). Shipment of Radioactive Material by the U.S. Department of Energy. Reference \#002.

U.S. Department of Energy (08/01/89). Transporting Radioactive Material...Answers to Your Questions. Reference \# 0 ; .

U.S. Department of Energy (01/01/86). Shipment of Radioactive Materials by the U.S. Department of Energy. Reference \#023. 
U.S. Department of Transportation (05/01/83). Community Teamwork: Working Together to Promote Hazardous Materials Transportation Safety (A Guide for Local Officials). Reference \#(008.

U.S. Nuclear Regulatory Commission (06/01/92). Public Information Circular for Shipments of Irradiated Reactor Fuel. Reference \#093.

U.S. Nuclear Regulatory Commission (03/01/87). Transporting Spent Fuel: Protection Provided Against Severe Highway and Railroad Accidents. Reference \#094.

U.S. Nuclear Regulatory Commission (03/01/80). Information Package on Spent Nuclear Fuel Shipments for Law Enforcement Agencies. Reference \#013.

Western Interstate Energy Board (06/01/85). Spent Nuclear Fuel and High Level Radioactive Waste Transportation Primer. Reference $\$ 040$.

Western Interstate Energy Board (06/01/85). Spent Nuclear Fuel and High Level Radioactive Waste Transportation: White Paper. Reference \#041.

Willis, John M. . Pilot Test of Vehicle Inspection Procedures for the Highway Shipment of Spent Fuel. Reference \#049.

Wilmot, Edwin L., and Robert E. Philpott $(01 / 01 / 86)$. Transportation Systems to Support the Nuclear Waste Policy Act of 1982. Reference \#098.

\section{WIPP}

(11/08/90). TRANSAX '90: WIPP Shipment Exercise Program Full-Scale Orientation Exercise.

Reference \#007.

Baratti-Sallani, Patty (06/19/90). Waste Isolation Pilot Plant Update. Reference \#001.

Colorado Division of Disaster Emergency Services. Waste Isolation Pilot Plant and Transuranic Waste Shipments Through Colorado (Background Information). Reference \#010.

General Accounting Office (06/13/91). Delays in Addressing Environmental Requirements and New Safety Concerns Affect DOE's Waste Isolation Pilot Plant. Reference \#013.

General Accounting Office (06/01/90). Information on DOE's Interim Transuranic Waste Storage Facilities. Reference \#008.

General Accounting Office (12/01/89). Storage Issues at DOE's Waste Isolation Pilot Plant in New Mexico. Reference \#014.

Kouba, S., Gerald G. Boyd, Vince J. McClelland, and Jeff Everitt. TRANSAX '90: An Integrated Transportation Emergency Response Exercise Program Involving Transuranic Waste Shipments. Reference \#006.

Kouba, Steve (Westinghouse). Emergency Response Training Program. Reference \#011.

Lippis, Joe (11/14/89). WIPP Program Update. Reference \#003. 
Morris, Grady (06/21/90). Southern States Energy Board TRU Waste Transportation Working Group Update. Reference $\# 005$.

Southern States Energy Board (09/01/90). Proposal for Federal Financial Assistance to the Southern States to Ensure the Safe Transportation of Transuranic Waste. Reference \#012.

Southern States Energy Board (06/21/90). TRU Waste Transportation: Overview. Reference \#004.

U.S. Department of Energy (01/01/92). TRANSAX-90 - A Transportation Exercise Involving a TRUPACT-II Container (Videotape). Reference \#015.

Waste Isolation Pilot Plant. Waste Isolation Pilot Plant (Information Parkage). Reference \#002.

Western Governors' Association (06/01/89). Report to Congress: Transport of Transuranic Wastes to WIPP: State Concerns and Proposed Solutions. Reference \#009. 
Midwestern High-Level Radioactive Waste Transportation Project

\section{Publications}

Midwestern Radiological Emergency Preparedness and Response Agency Report, May 1990, 43 pages, $\mathrm{DOE} / \mathrm{CH} / 10402--2$. For twelve Midwestern states, this document reports on state agencies with emergency preparedness and response duties, providing specific information on radiological emergency response plans, agency responsibilities, contacts at the state level, and inventories of equipment for use during a radiological emergency.

Rudioactive Materials Transportation Safety Training Report, May 1990, 16 pages, DOE/CH/10402--3. This report looks at Midwestern state programs for training emergency response personnel to handle transportation accidents involving radioactive materials.

Report on Mutual Aid Agreements for Radiological Transportation Emergencies, May 1990, 10 pages, $\mathrm{DOE} / \mathrm{CH} / 10402-4$. This report looks at existing interstate emergency response mutual aid agreements in the Northeast, South and West, and examines how similar agreements among Midwestern states may facilitate emergency response to transportation accidents involving radioactive materials.

Model State Mutual Aid Agreement, December 1990, 6 pages, DOE/CH/10402-5. This document provides a model of a state mutual aid agreement to serve as a starting point for discussion between Midwestern state officials interested in forming such an agreement for transportation emergencies involving radioactive materials.

Midwestern High-Level Radioactive Waste Transportation Primer, May 1991, 108 pages, DOE/CH/10402-9. A major milestone for the Transportation Project, the Primer discusses the objectives and challenges to implementing the federal Nuclear Waste Policy Act, with a focus on the institutional issues surrounding the transportation of spent nuclear fuel and high-level radioactive waste.

Midwestern States Highway Routing Report, November 1991, 16 pages, DOE/CH/10402--10. This report identifies those agencies in Midwestern states that hold specific authority to designate alternatives to the preferred routes established under federal guidelines for transporting high-level radioactive waste.

Timing and Funding of Emergency Response Training in Midwestern States, November 1991, 14 pages, $\mathrm{DOE} / \mathrm{CH} / 10402-14$. By providing information on critical lead times for planning and delivering emergency response training courses in Midwestern states, this report provides a basis for determining the appropriate time to begin federal training assistance mandated by the Nuclear Waste Policy Act.

Highway Infrastructure Report, February 1992, 26 pages, DOE/CH/10402--16. This document compiles information on recent or planned state- and county-sponsored work projects targeting roads near nuclear power plants in the Midwest.

Handbook of High-Level Radioactive Waste Transportation, October 1992, 44 pages, DOE/CH/10402--19. This document condenses and updates information first presented in the Midwestern Primer of High-Level Radioactive Waste Transportation. The Handbook serves as a reference to which state officials and the general public may turn for information regarding radioactive waste transportation and the federal Civilian Radioactive Waste Management Program. 
DATE

FILMED

$3 / 2 / 93$ 
